OPEN ACCESS

Edited by:

Ron Shaoul,

Rambam Health Care Campus, Israel

Reviewed by:

Stefano Guandalini,

University of Chicago, United States

Tudor Lucian Pop,

Iuliu Haţieganu University of Medicine

and Pharmacy, Romania

${ }^{*}$ Correspondence:

Markku Mäki

markku.maki@tuni.fi

†These authors have contributed equally to this work

Specialty section: This article was submitted to Pediatric Gastroenterology, Hepatology and Nutrition,

a section of the journal

Frontiers in Pediatrics

Received: 15 May 2019 Accepted: 15 August 2019

Published: 29 August 2019

Citation:

Popp A and Mäki M (2019) Changing Pattern of Childhood Celiac Disease Epidemiology: Contributing Factors.

Front. Pediatr. 7:357.

doi: 10.3389/fped.2019.00357

\section{Changing Pattern of Childhood Celiac Disease Epidemiology: Contributing Factors}

\author{
Alina Popp ${ }^{1,2 \dagger}$ and Markku Mäki ${ }^{1 *+}$ \\ ${ }^{1}$ Faculty of Medicine and Health Technology, Tampere Center of Child Health Research, Tampere University and Tampere \\ University Hospital, Tampere, Finland, ${ }^{2}$ National Institute for Mother and Child Health "Alessandrescu-Rusescu", University of \\ Medicine and Pharmacy "Carol Davila", Bucharest, Romania
}

Up until the 1960s and 1970s, diarrhea, malabsorption syndrome, and failure to thrive were the presenting symptoms and signs of celiac disease (CD) in young infants; however this disease was also at the same time reported to be disappearing. Indeed, clinical childhood CD was seen to transform into a milder form, resulting in an upward shift in age at diagnosis during the 1970s (and years later for many countries). This changing pattern of $C D$ presentation then altered the epidemiology of the disease, with major differences between and within countries observed. An awareness of the changing clinical nature of $C D$ and use of case-finding tools to detect even clinically silent $C D$ became an important factor in this changing epidemiology. Countries report both low and high prevalence but it seems to be on the increase resulting in a population-based level of $1-2 \%$. This paper discusses the potential causes and environmental factors behind these observed clinical changes, identifying new clues from different studies published at the time this transformation took place. For instance, it was found that breastfeeding postponed the diagnosis of the disease but did not altogether prevent it. Moreover, gluten introduction at a young age, specifically at the mean age of 2 months, seemed to also have a clear impact in inducing malabsorption syndrome and failure to thrive in young infants in addition to other factors such as gluten intake volume and type of cereal present in the weaning food. Further, the impact of cow's milk and its high osmolarity might have played an important role; humanized milk formulas were not yet invented. Future epidemiological studies on the contributing environmental factors to the shift in $\mathrm{CD}$ presentation are thus recommended for countries in which these changing clinical features are still being observed.

Keywords: celiac disease, changing pattern, incidence, prevalence, infant feeding, autoimmunity, awareness, screening

\section{INTRODUCTION}

Celiac disease $(\mathrm{CD})$ has earlier been considered to be a rare intestinal disease occurring only in children, a disease that Samuel Gee in 1888 presented as the "coeliac affection" (1). As summarized by John Walker-Smith, Gee was very accurate in his description of childhood CD: "it is a kind of chronic indigestion, which is especially apt to affect children between 1 and 5 years old and where signs of the disease are yielded by the feces, being loose, but not watery, bulky, and pale. 
The onset of the disease is usually gradual and cachexia is a constant symptom. The belly is mostly soft and often distended" (2). The conception on CD changed in early 1950 s by the discoveries of Dicke, who showed that the cause of harm in patients with $\mathrm{CD}$ was dietary gluten; in fact, he specifically noted that the disease was not caused by all cereals but, specifically, wheat flour (3). The next major research discovery occurred in the 1950s and involved the use of a peroral intestinal suction biopsy apparatus as a diagnostic tool. When gluten was ingested by children with $\mathrm{CD}$, the development of a characteristic mucosal lesion in the jejunum was observed, namely villous atrophy with crypt hyperplasia (4). Moreover, new biopsy criteria were adopted early on in Europe by the European Society for Pediatric Gastroenterology, even for young infants (4-6).

Celiac disease (CD) was long thought to be a rare disease, occurring only in children with a classical presentation known as malabsorption syndrome and failure to thrive (7). However, today, $\mathrm{CD}$ is known as an autoimmune systemic disorder occurring in genetically susceptible individuals and perpetuated by the daily ingestion of gluten cereals (i.e., wheat, rye, and barley) with manifestations both in the small intestine and in extraintestinal organs $(7-10)$. CD is more complex than simple intestinal malabsorption, which is, in fact, no longer essential for diagnosis. Another important milestone in CD diagnostics and screening was the discovery and clinical use of highly CD-pathognomonic, circulating, gluten-dependent tissue autoantibodies measured within the immunoglobulin A (IgA) class (11-18). Awareness of the disease and use of these tools have come to determine the epidemiological outcome in $\mathrm{CD}$ research. Furthermore, late-developing, small-intestinal mucosal injury also plays a role in the changing pattern and epidemiology of CD. In other words, this refers to a CD latency in which the disease exists but is not manifested at the mucosal level, even if the patient has ingested gluten for decades (9). Susceptibility to CD is inherited; however, upon a child's first encounter with gluten he may or may not develop the disease at a small-intestinal mucosal level soon thereafter. Oral tolerance toward gluten can persist for a long period of time with the deterioration of the mucosa possibly taking place at a later age. This also explains the late mucosal relapses during gluten challenges and late appearing mucosal injury concordance in monozygotic twins as well as possibly spontaneous mucosal recoveries upon continued gluten ingestion.

Celiac disease (CD), known as a rare malabsorption syndrome in young Caucasian children has, since the 1970s, come to be known as a common, chronic, food-induced autoimmune systemic disorder world-wide, diagnosed in children, adolescents, adults, and the elderly. The changes in perception of $\mathrm{CD}$ as a clinical disease and observed changes in occurrence have been remarkable during the past 50 years. In these aspects, there are, however, several differences between countries and continents. This review thus discusses the pattern of change in childhood CD presentation, its influence on its epidemiology, increasing incidence rates, and the causes behind them.

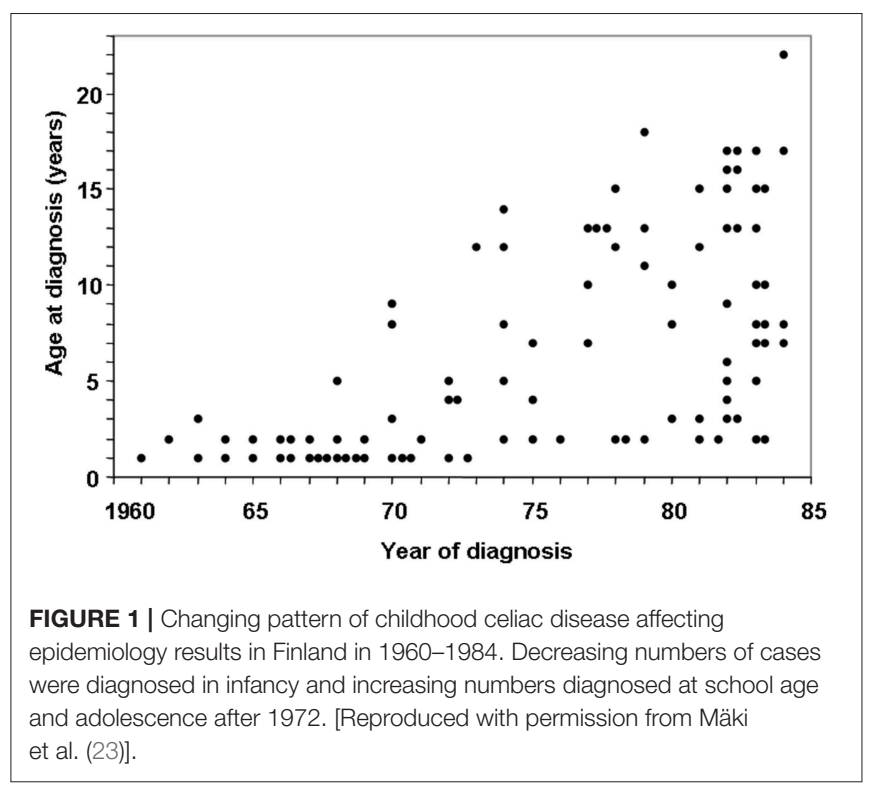

\section{CHANGING CLINICAL FEATURES}

In the 1960s, a child with CD typically presented with prolonged diarrhea, malabsorption syndrome, and failure to thrive, often before the age of 2 (7). However, a shift in CD presentation became evident during the 1970s and 1980s, with childhood CD reportedly disappearing altogether (19-22). In Finland, however, from 1970 onward, it was observed that, in addition to the disappearance of the classical form of CD in young children, the incidence rates of the milder forms of the disease increased, resulting in an upward shift in age at diagnosis from 2 to 8 years (Figure 1) (23). This was also evident in the UK, with a changing disease pattern seeming to be a fact; childhood CD tended to present at later age (24).

When CD manifests during the later stages of childhood, symptoms can be gastrointestinal; however the disease is often monosymptomatic, presenting with short stature, delayed puberty, and joint pain or anemia due to isolated iron deficiency $(23,25-30)$. Gastrointestinal symptoms may also be mild or non-existent. If the healthcare professionals are diagnosing only classical CD presenting at young age and older children with gastrointestinal symptoms, only the tip of the iceberg of all CD patients are detected (Figure 2), epidemiologically resulting in low incidence and prevalence numbers. These clinically silent patients, i.e., children with no symptoms or signs suggesting $\mathrm{CD}$, also exhibit a gluten-triggered and -dependent small intestinal mucosal lesion manifestation (Figure 2). They require an increased awareness of healthcare professionals and a case-finding strategy for early diagnosis. Specifically, celiac autoantibody testing can determine an underlying gluteninduced disease, yielding high sensitivity and specificity (1118). The existence of clinically silent patients became evident when performing gluten challenges to earlier diagnosed welltreated patients $(31,32)$ in addition to CD screening for certain risk groups, such as those with type 1 diabetes $(13,18)$ or 


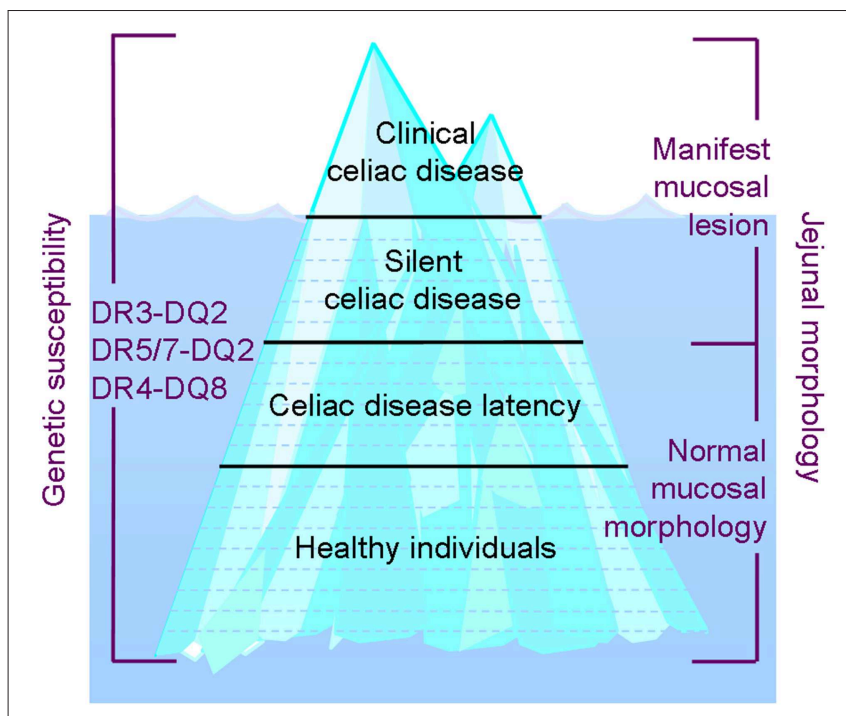

FIGURE 2 | The celiac disease (CD) iceberg and the spectrum of celiac trait: Awareness of different clinical forms of CD and clinicians' activity in case-finding by screening will influence the outcome of incidence rates and prevalence in different countries and within countries.

healthy, first-degree family members $(33,34)$. Case-finding using celiac-pathognomonic serum IgA class R1-type reticulin autoantibodies $(11,12)$, later known as endomysial and tissue transglutaminase antibodies $(14,15)$, detected the clinically silent patients and helped change the perception of childhood CD. The changing pattern of CD epidemiology would partly go unnoticed, if healthcare professionals are not aware of the existence of clinically silent CD and use a case-finding strategy in diagnostics.

Latent CD refers to the fact that the disease exists but does not manifest at the mucosal level until at some later age. The small intestine mucosa can stay intact upon years and decades of full gluten ingestion, or the mucosal damage can develop gradually. Final deterioration of the mucosa occurs when oral tolerance toward gluten ceases $(9,35)$ (Figure 2). We have extensively discussed latent and developing CD in a recent review article (9). Latent CD patients may be serum autoantibody positive, have a normal small intestine mucosa and thus according to biopsy criteria be excluded for CD. These patients may even become serum autoantibody negative upon normal gluten ingestion but still develop the disease at some later age (36). Stenhammar et al. addressed the latency issue in CD family studies spanning 20 years $(37,38)$. When a small intestine biopsy was performed for 100 first-degree relatives of index patients with childhood CD in 1982 , only $2 \%$ were found to have clinically silent CD. When they reinvestigated all first-degree relatives of the same index patients 20-25 years later, eight new cases of CD were detected $(8.3 \%)$, two of whom were found not to have the disease in the first study. Eleven more relatives exhibiting mild enteropathy were identified in the new screening, and it was suggested that they were followed carefully for potential development to overt disease. CD incidence and prevalence figures are influenced by the age of the patients at time of study and also whether a changing pattern of childhood CD has taken place in the country or setting where the study was performed.

A large European study involving 38 centers and 5,871 children with diagnosed CD confirmed that there had been an overall mean increase in age at diagnosis from 2 years in 1975 to 4 years in 1990 (39), with Sweden being the exception (40). The changing CD pattern has been described as occurring at different times within and without different countries. In the Naples region of Italy, for example, no change in age at diagnosis was observed between 1973 and 1986 (41). In some other parts of Italy, however, an increase in age was observed (39), with classical forms of CD decreasing in the late 1990s and early 2000s and silent forms significantly increasing, resulting in an increased age at diagnosis as well (42). Similarly, no changes in the overall clinical makeup of CD could be found in the Netherlands between 1975 and 1994 (43) but an increased awareness and recognition of childhood CD did ultimately change the clinical presentation during the years 1993-2000 (44). In the UK, considerable changes were reported mostly due to targeted serum antibody screening. A decrease in the proportion of patients presenting with gastrointestinal manifestations and a rise in the number of patients without symptoms was also observed (45). This change was still occurring in the UK during the years 2005-2011, with over 50\% of children diagnosed with CD exhibiting few or no symptoms (46). This same type of changing clinical pattern has been observed in Greece (47), North America (48-50), India (51, 52), Estonia (53), Turkey (54), and Sweden (although, in this case, only after mid-1990s when the Swedish epidemic occurring in young infant from 1985 to 1995 had ended) (40, 55). In Finland, between 1975 and 1990, large differences in CD incidence rates were found when comparing Helsinki to Tampere (39), since an awareness of clinically silent CD was not acknowledged by primary health care professionals in the capital of Finland. Later, however, in Helsinki, the number of patients with $\mathrm{CD}$ was found to increase six-fold between 2000 and 2005, with mean age at diagnosis increasing to 7.2 years (56). When comparing the two neighboring countries of Finland and Sweden based on CD's clinical features from 1985 to 1989, the differences found were remarkable: in Sweden, classical clinical symptoms and a diagnosis before the age of two was most commonly observed, whereas, in Finland, symptoms varied much more greatly, and diagnosis was often made after the age of 8 (57). However, the presentation of CD in Finnish children seems to no longer be shifting, with a plateau having been reached in recent years (58).

These observed changes in clinical presentation had inevitable effects on the epidemiological outcomes of CD and were, in terms of timeframe and magnitude, not similar between and among the different countries. It is thus difficult to compare different CD incidences from different publications and countries. Overall, a change in the pattern of symptom presentation for childhood $\mathrm{CD}$ that is in line with early observations has been noted in the textbooks as well as in CD guidelines worldwide (7, 59-61).

In Finland, during the 1970s, there was a growing awareness of the aforementioned changing $\mathrm{CD}$ pattern, as shown in Figure 1, which influenced health care professionals' case-finding via screening. In fact, this awareness seemed to be the major 
factor involved in the changing epidemiology and increasing incident rate observed in older children. However, it should be noticed that changing epidemiology is also a result of whether disease-specific autoantibody tools are used for casefinding in the primary healthcare field instead of only in secondary or tertiary referral centers. Today, children with CD are not often so symptomatic that they would need to be admitted to pediatric gastroenterology centers. Furthermore, case-finding using autoantibody screening and a high index of disease suspicion is in our experience a prominent diagnosis method in primary care. Finland also experienced a decrease in the yearly incidence rate during the economic crisis of the early 1990s, during which the city of Tampere health authority forbade primary care doctors to use reticulin or endomysial autoantibodies as case-finding tools, suggesting instead the cheaper but outdated crude gliadin serum antibody test. The authority intervention resulted within a 2-year timeframe in a three-time decrease of biopsy-verified diagnoses at the referral center.

The current major question in pediatrics asks what has caused the described change in the clinical presentation of CD over time. When addressing the changing epidemiology of childhood CD in 1992 (39), we suggested the following environmental factors to play a role: genetic background of the population, infantile gastroenteritis/other infections, unmodified/adapted cow's milk formulas, breastfeeding, age at gluten introduction, quantity of gluten, quality of cereals, and quality of wheat gluten (62). These environmental factors will be discussed here in more detail. The present review is not extended to include human leukocyte antigens (HLA), non-HLA genes, or other genetic aspects in populations with low prevalence rates of $\mathrm{CD}$, such as those comprised of black Africans or Japanese individuals, but did include environmental factors in populations with similar HLA DQ2 and DQ8 background. Environmental factors have an evident impact on intestinal epithelial cells, either through direct interaction or through microbiota. This review does not address any potential epigenetic mechanisms, such as histone modifications, DNA methylation, or microbial RNA methylation, as indicators of the changing pattern in CD epidemiology over time.

\section{ENVIONMENTAL FACTORS BEHIND CHANGING PATTERNS OF CELIAC DISEASE}

\section{Infant Feeding Patterns Breastfeeding}

As early as 1953, Andersen and di Sant'Agnese found that breastfeeding for a duration of more than 2 months delayed the onset of diarrhea in patients with CD (63). Moreover, two case-control studies performed in Italy indicated breastfeeding protected patients against CD $(64,65)$. When evaluating whether the duration of breastfeeding influenced age at diagnosis, a mean increase in breastfeeding from 2.5 months in children born from 1961 to 1965 to 3.9 months in children born from 1976 to 1980 was observed. Furthermore, a significant correlation was found between age at diagnosis and duration of breastfeeding in a study of 45 children diagnosed with CD before the age of 6 years, with breastfeeding found to delay the onset of symptoms (23). Thus, prolonged breastfeeding seemed to prevent the development of $\mathrm{CD}$ but did not protect patients against the disease, since it manifest at a later age. Overall, the median age at diagnosis was 8.8 years in Tampere, Finland during the early 1980s (39). In the neighboring country of Sweden, at the time of their CD epidemic in 1985-1995 (described below) and a national trend in short breastfeeding duration (40), the median age at childhood diagnosis was 1.3 years (57). Table 1 shows the percentages of Finnish, Italian, and Swedish children breastfed at the ages of 6, 9,

TABLE 1 | Amounts of ingested gluten-containing cereal proteins ( $\mathrm{g}$ per protein per kg body weight per day) and percentage of breastfeeding of healthy Finnish (Tampere), Swedish (Gothenburg) and Italian (Naples) infants at 6, 9, and 12 months of age in 1990 at the time of the Swedish epidemic [adapted from Ascher et al. (57) and Mäki et al. (62)].

\begin{tabular}{|c|c|c|c|c|c|c|c|c|c|c|}
\hline & \multirow[t]{2}{*}{$n$} & \multicolumn{2}{|c|}{ Wheat } & \multicolumn{2}{|c|}{ Rye } & \multicolumn{2}{|c|}{ Barley } & \multicolumn{2}{|c|}{ Oats } & \multirow[b]{2}{*}{$\begin{array}{c}\text { Breast-feeding } \\
\%\end{array}$} \\
\hline & & Mean & SD & Mean & SD & Mean & SD & Mean & SD & \\
\hline \multicolumn{11}{|l|}{6 months } \\
\hline Tampere & 73 & $0.06^{a}$ & 0.06 & 0.02 & 0.03 & 0.01 & 0.02 & 0.20 & 0.23 & 71 \\
\hline Naples & 50 & $0.44^{\mathrm{a}}$ & 0.24 & & & & & & & 10 \\
\hline \multicolumn{11}{|l|}{9 months } \\
\hline Tampere & 60 & $0.14^{\mathrm{a}}$ & 0.09 & 0.08 & 0.10 & $0.03^{a}$ & 0.04 & $0.25^{a}$ & 0.17 & 47 \\
\hline Gothenburg & 20 & $0.48^{a}$ & 0.21 & 0.04 & 0.05 & $0.01^{a}$ & 0.01 & $0.16^{a}$ & 0.14 & 20 \\
\hline Naples & 58 & $0.6^{a}$ & 0.23 & & & & & & & (1 child) \\
\hline \multicolumn{11}{|l|}{12 months } \\
\hline Tampere & 47 & $0.20^{a}$ & 0.13 & 0.12 & 0.12 & 0.03 & 0.03 & 0.23 & 0.15 & 17 \\
\hline Gothenburg & 13 & $0.42^{a}$ & 0.13 & 0.09 & 0.05 & 0.02 & 0.02 & 0.20 & 0.19 & 0 \\
\hline Naples & 58 & $0.60^{a}$ & 0.25 & & & & & & & 0 \\
\hline
\end{tabular}

a Significant difference between countries.

In Naples no rye, barley, or oats was consumed. 
and 12 months during a time in which the diagnoses of children under two displayed values of 7,40 , and $74 \%$, respectively (57, $62)$. At the same time, in the UK and Ireland, it was observed that breastfed babies presented with CD later than their bottlefed counterparts $(22,24)$. In 2002, Ivarsson et al. revealed the protective effect of breastfeeding against CD (66).

As the research has suggested, breastfeeding may prevent the development of CD. Thus, Akobeng et al. conducted a systematic review and meta-analysis of certain observational studies published between 1966 and 2004 (67). The meta-analysis showed that the risk of CD was significantly reduced in infants who were breastfed at the time of gluten introduction (pooled odds ratio of $0.48,95 \%$ CI $0.40-0.59$ ) compared with infants who were not breastfed during this period. A systematic review from 2012 provided a similar picture, with the study concluding that certain studies indicate a protective effect of breastfeeding, while others do not. The meta-analysis reported a lower risk of CD in breastfed infants, further stating, however, that it was unclear whether those breastfed received permanent protection from CD (68).

In 2016, a position paper by the European Society for Pediatric Gastroenterology, Hepatology, and Nutrition (ESPGHAN) stated that breastfeeding has not been shown to reduce the risk of CD in children (69). Indeed, new evidence on breastfeeding not to be protective against $\mathrm{CD}$ has emerged from prospective randomized clinical trials (70-72). However, the evaluated studies were not often designed to directly address the effect of breastfeeding on $\mathrm{CD}$. At the time of the changing pattern in $\mathrm{CD}$ presentation, prolonged breastfeeding in Finland was associated with a postponed diagnosis of $\mathrm{CD}$ but not with its prevention altogether (23). This effect was also observed in Ireland and the UK $(22,24)$ at the same time, with breastfed infants diagnosed with CD later than their bottle-fed counterparts despite their similar ages at gluten introduction (24). These early reports indicate that breastfeeding could still have contributed to the changing epidemiology of CD (19-24).

\section{Age at Gluten Introduction}

In our study of the changing pattern observed in childhood CD presentation (Figure 1), no correlation between age at diagnosis and time of gluten introduction was found (23). Meijer et al. presented recent studies as evidence of the effect of gluten introduction timing and the associated risk of $\mathrm{CD}$ in young children (73), concluding that it did not influence the risk of $\mathrm{CD}$, as also suggested by the results of large prospective studies. Furthermore, the position paper by ESPGHAN in 2016 recommended (a) to not introduce gluten while the infant is being breastfed as a means of reducing the risk of developing CD (i.e., decreasing the incidence rate of CD); (b) gluten introduction at age 4-6 months, compared to gluten introduction at age $>6$ months, does not reduce the cumulative incidence rate of CD in children; (c) for children at a high risk of CD, gluten introduction at 6 months of age compared to 12 months of age does not reduce the cumulative incidence rate of $\mathrm{CD}$ but instead leads to earlier manifestations; (d) it remains unclear whether gluten introduction at age $<3-4$ months compared with 4-6 months has an effect on the risk of developing CD; and (e) it remains unclear whether gluten introduction at age $<3-4$ months compared to gluten introduction at age $>6$ months has an effect on the risk of developing CD (69).

Even if the current available evidence suggests that age at gluten introduction is not associated with the changing CD epidemiology, this review suggests that it could still have played an important role at the time when chronic diarrhea and failure to thrive disappeared as presenting clinical features of the disease (19-22, 24). It should be noted that in the 1960s and earlier, gluten was introduced to infants at a very early age. From 1960 to 1965 in Ireland, the mean age at gluten introduction for 130 newly diagnosed children was 2.3 months, while, from 1976 to 1981 , it was 4.2 months (22). Moreover, in the UK before 1975 , the median age at gluten introduction for diagnosed CD patients was 2 months, while, after 1975, it increased to 4 months (24). These changes in infant feeding patterns coincided with the observed change in CD epidemiology.

\section{Amount of Gluten and Quality of Cereals}

The amount and type of cereals an infant ingests may play an important role in the changing epidemiologic makeup of CD. Since major differences in the incidence rate and presentation of CD in Finland and Sweden were observed, a joint study was conducted to explore potential causes of the phenomena (57). The results from late 1980s showed that the Gothenburg region of Sweden reported 30 times more infants diagnosed with CD before the age of two than Tampere, Finland. At this time in Finland, cereals were implemented gradually into infant diets from the age of 5 months onward, with parents having a choice between different types of gluten-containing cereals (i.e., wheat, rye, barley, oat) or non-gluten-containing cereals (i.e., rice) in the form of gruels or porridge. On the contrary, in Sweden since 1982 , there has been a rapid introduction of gluten at the age of 6 months. Table 1 shows the results of a prospective study of dietary intake of gluten-containing cereals in two neighboring countries exhibiting highly significant differences in the amount of gluten ingested and in quality of cereals $(57,62)$. The Swedish infants at the age of 9 months ingested three times and at the age of 1 year twice the amount of wheat protein compared to their Finnish counterparts (Table 1). The same evaluation was at the same time conducted in Italy in the Naples region. In Italy, weaning food was completely wheat-based. When wheat, rye, barley, and oat proteins are counted at once, the figures of ingested gluten of the Nordic countries converged with those of Italy. The gluten amount ingested during infancy also correspond to the country differences in CD incidence and prevalence at that time $(23,40,41,57)$.

Here it should be noted that "gluten" (i.e., avenin) in oats is not CD-inducing (74-76). Therefore, another important aspect to consider why in the late 1980s Sweden experienced 30 times more infants diagnosed with CD before the age of 2 than Finland, is the amount of oats ingested by the infants: at the age of 9 months, Finnish infants ingested significantly more oat protein than Swedish infants (Table 1).

Low wheat intake has been thought to cause the low incidence rate of CD in the countries of Denmark (77) and Estonia (78). When comparing the prevalence of CD in Denmark vs. Sweden 
in 1987, it was estimated that, for infants at 8 months of age, the Swedish diet contained 40 times more gliadin than the Danish diet, while, at 12 months of age, it contained four times more. The weaning food in Denmark was based on rye not wheat (77). Rye gluten, i.e., secalin could actually be clearly less disease-inducing than wheat gluten, i.e., gliadin.

More recently, Cresco-Escobar et al. reported that gluten consumption patterns and the amount of gluten consumed between the ages of 11-36 do not influence CD development in children at a genetic risk for the disease (79). Furthermore, a new study from the US was able to link gluten intake volume in 1 -year-olds with the future onset of CD (80).

One further potential environmental factor in influencing the presentation of $\mathrm{CD}$ might be the changes in the glutenrich cereal varieties themselves because of wheat breeding. New hybridization techniques have been used to produce new strains of modern wheat where celiac-triggering gluten proteins are expressed to higher levels. These new strain do express even new gluten proteins on which no animal or human safety testing was conducted $(81,82)$.

\section{Cow's Milk as a Contributing Factor to CD}

The present review regarded also older publications from the time when changing clinical features were observed and infants were fed unmodified cow's milk. Important modern epidemiology literature using systemic reviews and metaanalyses has not discussed these studies. The third important contributing factor to changing CD epidemiology in infancy, in addition to the introduction of breast milk and gluten, might in fact be the use of cow's milk.

During the 1960s, young children from the Tampere region diagnosed with $\mathrm{CD}$ all received homemade, diluted, cooked, "half"- and "two-third"-cow's milk $(23,62,83)$. The shift from using diluted cooked cow's milk to humanized, i.e., more breast milk resembling cow's milk-based infant formulas took place in Finland during the year 1972. This, together with the decrease in the amount of ingested gluten as a result of prolonged breastfeeding, could have significantly contributed to the disappearance of the symptomatic forms of $\mathrm{CD}$ in young children. In the UK, bottle-fed infants presented earlier with CD when compared to breast-fed infants (24). This was true both prior to 1975 when gluten was introduced at a median age of 2 months as well as after 1975 when gluten was introduced at a median of 4 months. Before the mid 1970s, most artificiallyfed Irish infants received formulas containing unmodified cow's milk, with the total protein content and osmolarity of such formulas both reduced at the same time as the decreasing incidence rate of CD was observed. Humanized infant formulas were implemented from 1978 onwards both in the UK and Ireland (22).

Kuitunen et al. reported that malabsorption syndrome caused by cow's milk protein intolerance in patients from 1962 to 1971 was a clear-cut clinical entity; gluten was not the causing factor of the disease (84). Moreover, small-intestinal biopsies obtained from these infants showed that the jejunal mucosa was injured, the patients displayed villous atrophy with crypt hyperplasia that was undistinguishable from that of untreated CD. The development of a so-called flat lesion was observed in approximately half of the patients (84-86). During the 1960's, a high incidence rate of cow's milk intolerance at infancy was found in diagnosed CD. Kuitunen et al. suggested that cow's milk intolerance may "pave the way" to CD (85).

A recent study by Hyytinen et al. did not find evidence that weaning off a diet of extensively hydrolyzed formula (compared to the implementation of cow's milk-based formula) would decrease the risk of CD later in life (87). It is not clear whether the breastfeeding and gluten introduction timelines presented in this study (87) are comparable with those from the previous, aforementioned studies (22-24). Furthermore, it is also currently unclear whether the cow's milk formula used by Hytinen et al. (87) (80\% intact milk protein, Enfamil; Mead Johnson, Chicago, IL, USA, and $20 \%$ hydrolyzed milk protein) mimicked the protein content and osmolarity of the homemade, cooked, diluted cow's milk used during the 1960s and early 1970s.

\section{National Recommendations Causing Celiac Disease ("The Swedish Epidemic")}

Celiac disease (CD) is an example of when a national recommendation can modify a disease's epidemiology. The trend in Europe of disappearing infant $\mathrm{CD}$ and the shift of age at diagnosis $(19-24,38)$ was not observed to be the same among all countries, with Sweden being an exception (40, 57, 77). In 2000, Ivarsson et al. investigated the countrywide epidemic of chronic malabsorptive syndrome occurring during infancy for a 10 -year period from 1985 to 1995 . The annual incidence rate of $\mathrm{CD}$ in children $<2$ years of age was found to increase four-fold during the epidemic in Sweden (40). Before the epidemic in 1983, recommendations for age at gluten introduction changed from 4 to 6 months of age, and as previously discussed, there was a rapid introduction of a high amount of gluten at the age of 6 months, inducing CD. In 1983, due to national recommendations, the amount of gluten in industrially produced weaning food in Sweden had been doubled on average. The curve presented by Ivarsson et al. for the wheat-rye-barley index based on the estimated average daily consumption of gluten-containing follow-on formulas followed the pattern of the epidemic in this country (40). However, it was observed that oats were not included in this cereal index curve but the estimated average daily consumption of oats was given (40). So, the curve for oats consumption was drawn exhibiting a U-shape, suggesting that the less oats ingested, the higher the incidence rate of infantile $\mathrm{CD}$. The epidemic disappeared when wheat-based gluten content in the follow-on formulas was reduced (40). Table 1 shows the differences in cereal consumption patterns for the ages of 9 and 12 months in Sweden and Finland.

An important message from the Swedish CD epidemic is that authority directives can completely change the overall makeup of a disease over a short time period.

\section{Infections and the Microbiome}

Infantile gastroenteritis and other infections could be potential environmental factors functioning at the small intestine mucosal level and potentially leading to overt $\mathrm{CD}$ in children exhibiting normal mucosa (62). Furthermore, the rotavirus has been implicated as potentially triggering the onset of CD (88). A large cohort study of children with HLA risk alleles for CD 
found that frequent rotavirus infections (and not clinically symptomatic gastroenteritis) predicted a higher risk of CD autoimmunity (89). Furthermore, rotavirus infection increased $\mathrm{CD}$ autoimmunity, while vaccination seemed to reduce this risk (90). In fact, rotavirus infection may cause the manifestation of a small intestinal crypt hyperplastic injury with villous atrophy undistinguishable from the effects of gluten in $\mathrm{CD}$, which was observed in both an experimental animal model and a child with rotavirus infection (91, 92). Recently, an experiment performed by Bouziat et al. on a human reassortant reovirus infection in mice was shown to trigger inflammatory responses to dietary antigens (93). In their study also CD patients tended to present with higher incidence rates of anti-reovirus (but not the rotavirus) antibody levels compared to the controls. Bouziat et al. further concluded that their study in humans supported the role of the reovirus, a seemingly innocuous virus, in triggering the development of CD (93). Recently, an association between enterovirus infection and later CD presentation was also reported (94). Furthermore, there has been evidence that, in general, any type of infection could be associated with an increased risk of CD $(95,96)$.

Since the rotavirus has been implicated as potentially triggering the onset of $\mathrm{CD}$, live oral rotavirus vaccines could conceivably have a similar effect. However, a Finnish study in 2017 suggested that rotavirus vaccination did not increase the risk of $\mathrm{CD}$ in rotavirus-vaccinated children compared to those not vaccinated (97). In fact, rotavirus vaccination could even decrease the occurrence of CD in children and adolescents (98).

Tye-Din et al. discussed the complex role of microbiota in CD development (99). They found that factors such as environment, diet, and antibiotics can change the CD microbiome and its interactions with intestinal epithelial cells. The authors concluded that larger trials are warranted when microbiota are studied in at-risk individuals and must be followed-up with for a certain period of time to further understand genemicrobiome interactions in CD development (99). Recently, an observational, nationwide, register-based cohort study of children was performed in Norway and Denmark from 1995 to 2012 to elucidate the results of systemic antibiotic use in regard to CD (100), which indicated that childhood exposure to systemic antibiotics could be a risk factor of CD.

When examining the environment in which the changing pattern of $\mathrm{CD}$ occurred in children (Figure 1), robust epidemiological data supports the influence of gastroenteritis, especially of the bacterial variety rather than the rotavirusinduced disease (101). Figure 3 presents all cases of childhood diarrhea in the country reported to the National Board of Health in Helsinki, Finland over two 10-year periods. Diarrhea cases occurring during the summer, which produced large infant mortality rates, were seen to completely disappear during the 1970s in Finland. Moreover, the shape of the curve was now typical of the rotavirus infection, with the rotavirus also associated with half of all hospitalization cases from the years 1977 to 1978 (102). Additionally, enteropathogenic bacteria accounted for only $10 \%$ of all hospitalized cases. These were Yersinia, Campylobacter, certain strains of Salmonella, a few enteropathogenic Escherichia coli serotypes (EPEC), and zero Shigellas $(102,103)$. It should be noted that classical cases of CD

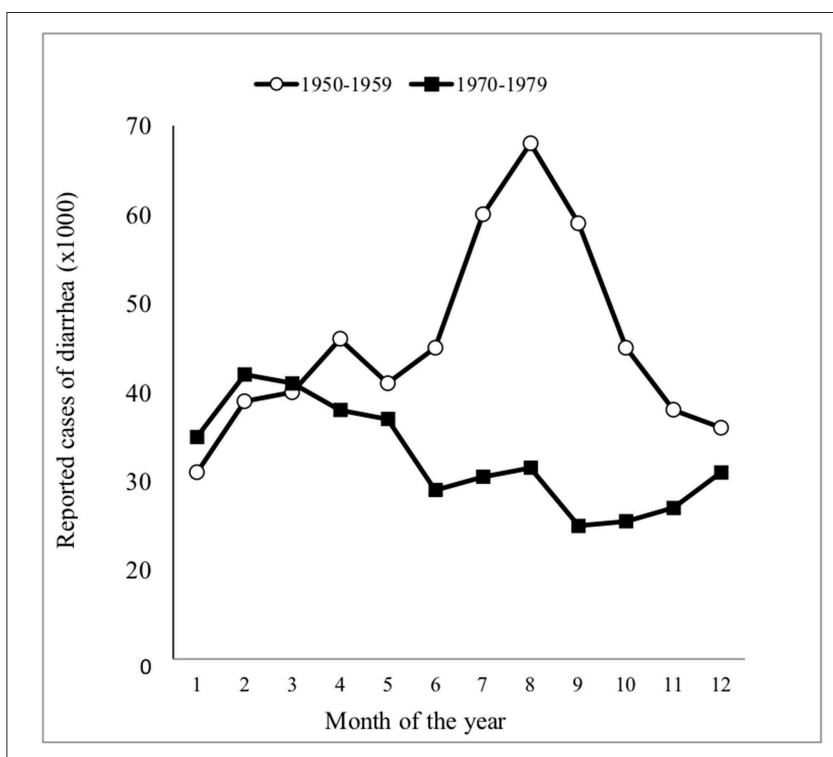

FIGURE 3 | Seasonal distribution of all reported cases of diarrhea in Finland during two 10-year periods [adapted from Mäki et al. (101)].

in young infants disappeared throughout Finland, even though the rotavirus was seen to greatly induce diarrhea and accounted for $50 \%$ of all hospitalization cases at that time (103). EPEC was seen to be most abundant during the summer months of the 1950 s and was detected in $24 \%$ of all diarrhea cases in children ages $0-3$ and in $28 \%$ of diarrhea cases for ages 3-6 months (101). Fewer "summer diarrhea" cases were reported during the 1960s; however, they were still quite prevalent and only completed to disappeared during the 1970s (101). Furthermore, the observed rate of hypertonic and hypotonic dehydration was only $3 \%$ in 1978, with $97 \%$ of all hospitalized children with diarrhea displaying isotonic dehydration (at the time when CD in infants had already disappeared) (101).

There are still some countries reporting the classical forms of $\mathrm{CD}$ in young children. For example, in Romania, enteropathogenic bacteria, EPEC, and infestations like giardia are all quite prevalent while very rare in Finland. Indeed, Romania is still currently experiencing several celiac crises, with eight new childhood cases occurring within just 1 year in Bucharest. On the other hand, general autoimmunity and pediatric chronic inflammatory bowel disease occur infrequently in Romania when compared to several other countries.

\section{Autoimmunity and the Hygiene Theory}

The increased prevalence of autoimmune diseases over time in industrialized countries is thought to be caused by a reduction in the incidence rate of infectious diseases, which is called the hygiene hypothesis. Early exposure to certain microorganisms during infancy directs and educates the human immune system. The frequency of infections directly contributes to an increase in autoimmune diseases, while infectious agents suppress autoimmune disorders $(104,105)$. Dysbiosis of commensal intestinal bacteria also plays an important role in autoimmune diseases, and the mechanisms inducing autoimmunity are a 
complex combination of various environmental factors. In one study, intestinal microbiome development was examined in children from ages 0-3 in Northern Europe, in which early-onset autoimmune diseases are common, particularly in countries like Finland, while less common in countries like Russia (106). The study then suggested that the immunogenicity of early colonizing symbiotic bacteria could be a potential contributing factor to autoimmunity in humans.

The fact that diarrheal diseases and infections trigger CD and that antibiotic treatment at an early age increases the risk of the disease have already been mentioned in this paper. At the same time, the hygiene theory argues that the presence of microbiota and infections at an early age are essential in suppressing subsequent autoimmunity. $\mathrm{CD}$ is, in fact, an autoimmune disease in which, in contrast to other autoimmune diseases, the driving force behind the disease is known: the daily ingestion of gluten (107-110). Furthermore, a shift in the pattern of CD presentation toward older age at diagnosis has been evident (23), with the disease altogether not prevalent in adults prior to the 1970s. Changes in the clinical features of the disease in adults were examined in a study conducted in Scotland from 1960 to 79 (111) and later in Finland, with an increased awareness and use of autoantibody case-finding tools (8) associating with CD's high prevalence in adults (112). In certain population-representative screening studies, an increased prevalence of CD autoimmunity was noted by age: $1.5 \%$ in children (113), $2.0 \%$ in adults (114), and $2.7 \%$ in the elderly (115). It was further shown that the prevalence of $\mathrm{CD}$ (i.e., autoimmunity) at the population level is increasing over time, doubling within the last two decades in Finland (114). Other studies later confirming this finding were conducted in the USA $(116,117)$. It has also been suggested that, for children, there is an increasing incidence over time $(118,119)$. Very recently, in fact, an increase in the prevalence in childhood CD was confirmed in Italy, showing a prevalence at the population level of $0.70 \%$ in 1994 and $1.58 \%$ in $2016(120,121)$.

In Russian Karelia, the population currently appears to be protected against autoimmune diseases. When compared to Finland, type I diabetes in children was six times less prevalent in Russia (122). A similar study comparing the prevalence of CD by screening 1988 schoolchildren from Russian Karelia and
3,654 children from Finland was performed and yielded the same result; $C D$ was five times less frequent in Karelia. This may be associated with a protective environment characterized by inferior prosperity and standard of hygiene in Russian Karelia (123). In Finland, decreased microbial exposure in childhood seems to lead to increasing prevalence of autoimmune diseases and CD. In Russian Karelia, understanding could be enhanced in regard to the environmental factors involved in CD protection, as long as the sharp environmental gradient across the border is still existing. Vatanen et al. (106) have already initiated such studies on the microbiome.

\section{INCIDENCE RATES AND PREVALENCE}

In the 1980s in Tampere, Finland, an increase in the number of childhood CD cases diagnosed annually were reported at the same time as a decrease in incidence rates in both the UK and Ireland were also reported (19-22). As shown in Figure 1, this was due to a greater awareness of the mild form of the disease and atypical cases among school-age children. Additionally, by the late 1970s, the use of the modern tissue autoantibody test of the IgA class began to be used in case-finding, i.e., the R1 reticulin antibody test, later called the endomysial (EMA), and the tissue transglutaminase antibody (TG2-ab) test $(12,15)$. In 1990, it was reported that a decrease in the incidence rate of CD for children under 2 years of age occurs but that at school age increased significantly (83). This is displayed in Table 2 where all children born in a strict geographical area during 1964-1988 were divided in 5-year birth cohorts and followed up to the age of 16 . Table 2 shows the numbers of $\mathrm{CD}$ patients diagnosed by the healthcare professional and the 5 -year birth cohort incidence rate per year for different ages and the total prevalence during childhood up the age of 16 . In the later birth cohort groups infant CD disappeared but the total prevalence of CD appeared stable during childhood (83). In terms of contracting the disease under 2 years of age, the risk for those born from 1964 to 1968 was 5.7-fold compared to those born from 1979 to 1983 or 1984 to 1988. Today, the children from the different birth cohorts are 30-55 yearsold, and the current prevalence of $\mathrm{CD}$ among the same group

TABLE 2 | Birth cohort incidence rate of 1,000 live births per year at different ages and total prevalence of celiac disease during 5 -year periods from 1964 to 1988 [adapted from reference Mäki and Holm (83)].

\begin{tabular}{|c|c|c|c|c|c|c|c|c|c|c|c|c|c|}
\hline \multirow{3}{*}{$\begin{array}{l}\text { Year of birth (No. of } \\
\text { live births) }\end{array}$} & \multicolumn{12}{|c|}{ Age of diagnosis (years) } & \multirow{3}{*}{$\begin{array}{c}\text { Total prevalence } \\
\text { (95\% confidence } \\
\text { interval) }\end{array}$} \\
\hline & \multicolumn{3}{|c|}{$<2$} & \multicolumn{3}{|c|}{$2-5$} & \multicolumn{3}{|c|}{$6-10$} & \multicolumn{3}{|c|}{$11-16$} & \\
\hline & $n$ & Incidence & $p^{a}$ & $n$ & Incidence & $p^{a}$ & $n$ & Incidence & $p^{a}$ & $n$ & Incidence & $p^{\mathrm{a}}$ & \\
\hline 1964-1968 (29 056) & 13 & 0.22 & & 3 & 0.03 & & 2 & 0.01 & & 11 & 0.06 & & $1.00[0.64-1.36]$ \\
\hline 1969-1973 (24 646) & 7 & 0.14 & NS & 3 & 0.03 & NS & 3 & 0.02 & NS & 8 & 0.05 & NS & 0.85 [0.49-1.22] \\
\hline 1974-1983 (25 962) & 4 & 0.08 & NS & 3 & 0.03 & NS & 7 & 0.05 & $<0.10$ & 10 & $(0.06)^{b}$ & NS & $(0.92)^{b}[0.55-1.29]$ \\
\hline 1979-1983 (25 466) & 2 & 0.04 & $<0.01$ & 4 & 0.04 & NS & 9 & $(0.07)^{\mathrm{b}}$ & $<0.025$ & & & & \\
\hline 1984-1988 (25 500) & 2 & $(0.04)^{b}$ & $<0.01$ & 4 & $(0.04)^{b}$ & NS & & & & & & & \\
\hline
\end{tabular}

a Significance as compared to the incidence for birth cohort 1964-1968.

${ }^{b}$ Not final incidence and prevalence but at least minimum value. 
TABLE 3 | Changes in incidence rates of childhood celiac disease over time.

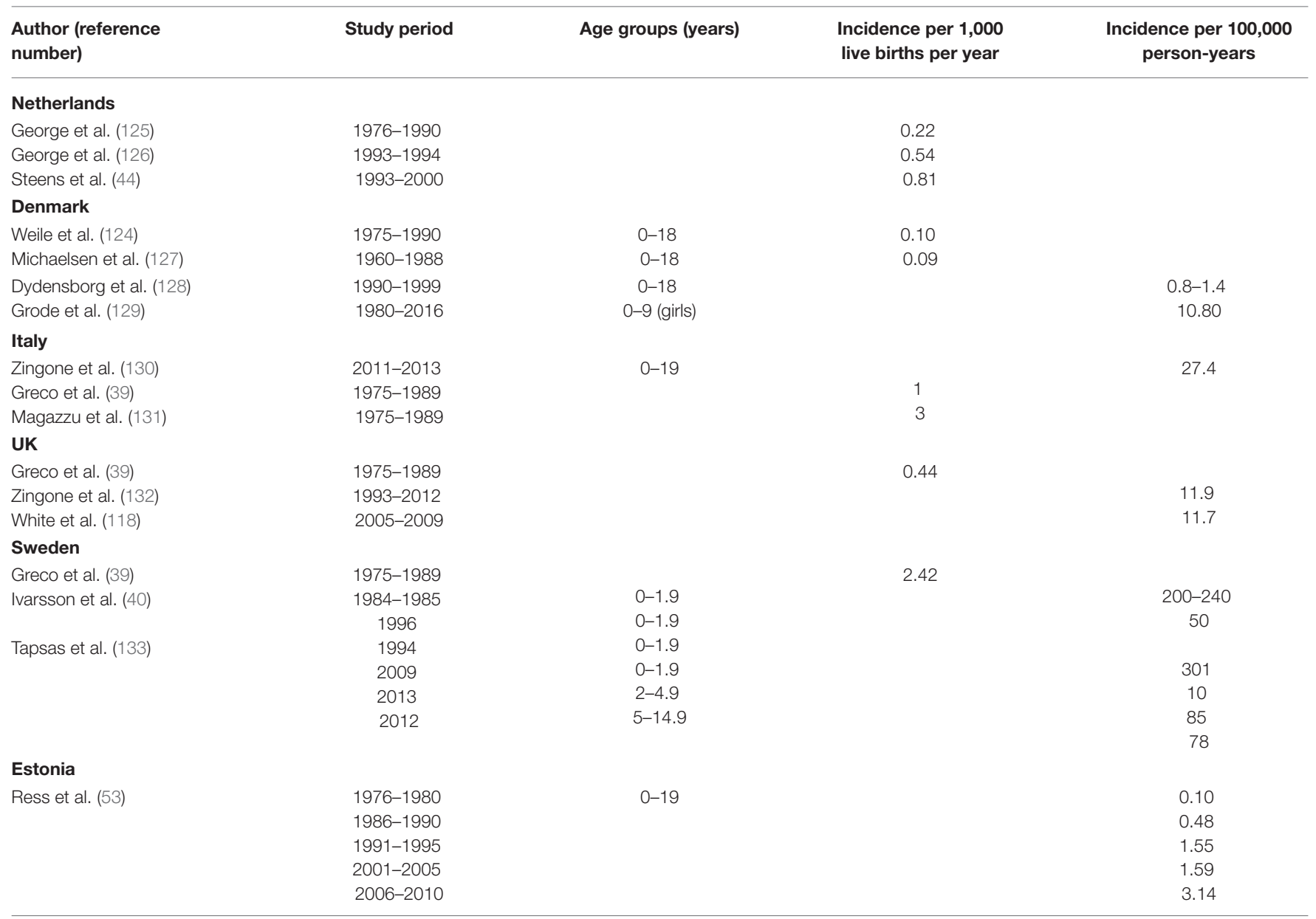

could be evaluated, which is probably not the $0.1 \%$ shown in Table 2 but rather 10-20 times higher, evidenced by populationbased screening studies and the established pattern of increasing prevalence over time $(113,114)$. In addition, these birth cohorts, when followed-up with for 30-50 years, could further provide insights into this increase in prevalence over time. Thus, it is hypothesized that, based on the prevalence of the increase in population-representative adult materials (114), the two 5-year birth cohorts from the years 1964 to 1968 and 1969 to 1973 present lower total CD prevalence than the three 5-year birth cohorts from the years 1974 to 1988 . However, it must be noted once more that, today, new seroconversions can still occur at older ages (115).

The lowest incidence rate per 1,000 live births (0.04) was reported in Estonia during the mid 1970s (78). In 2012, based on a nationwide study of childhood CD, Ress et al. showed a more than 30 -fold increase in the incidence rate over a 35 year period in Estonia (53) (Table 3). This was due to an awareness of existing even clinically silent CD and case-finding produced through an autoantibody screening. Denmark and The Netherlands similarly reported very low incidence rates that increased over the years (Table 3), which are speculated to potentially be due to changes in the environment $(124,125)$.
Table 3 also shows the selected incidence rates of CD of several different countries per 1,000 live births every year or per 100,000 people every year.

Table 4 presents childhood CD prevalence figures, including both the biopsy-supported and serologically detected (celiac autoimmunity) diagnosis types, from various parts of the world. The overall prevalence of CD was observed to be $\sim 1 \%$. However, population-representative screening further revealed that several countries, such as Argentina (135), Finland (113), Hungary (142, 143), Italy (121, 147-149), Spain (154), Sweden (157-160), and Turkey (163), were approaching a childhood prevalence of $1 \%$ or more. Meanwhile, countries exhibiting low CD prevalence included, among others, Estonia (138, 139), and Russia (123) (Table 4). The quite low prevalence rate observed for Denmark, even after its increase over the years (128), indicates that CD awareness is low among healthcare professionals and that serum autoantibody case-finding screening in the primary care field is not often performed. Furthermore, a questionnaire-based case-finding was conducted in Denmark in which children exhibiting celiac-related symptoms were invited to participate in a serological test. This evaluation showed that 14 out of 9,967 school-aged children suffer from CD in Denmark. For the same population, an additional 13 patients also had a 
TABLE 4 | Prevalence of childhood celiac disease and celiac autoimmunity in different countries.

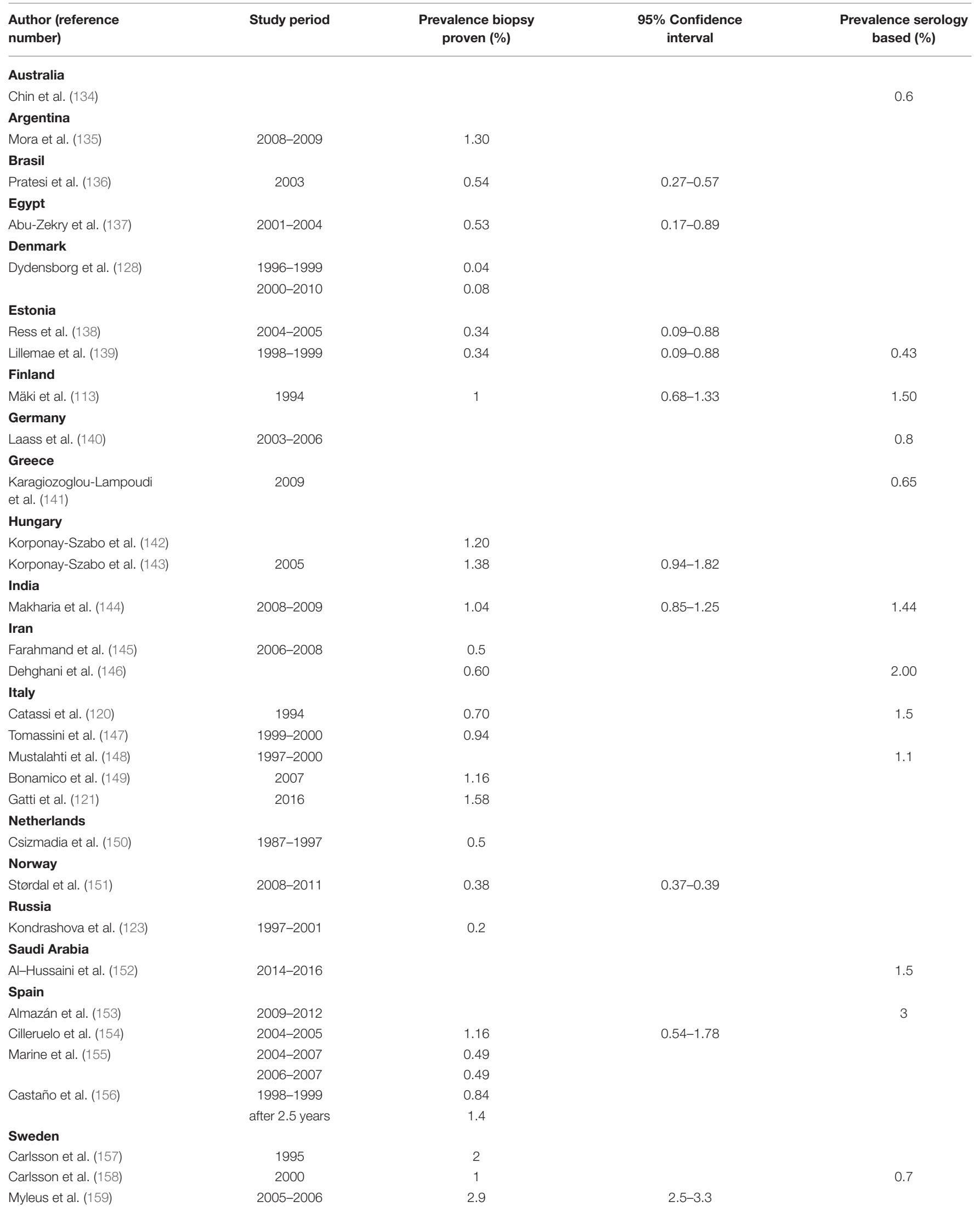


TABLE 4 | Continued

\begin{tabular}{lccc}
\hline $\begin{array}{l}\text { Author (reference } \\
\text { number) }\end{array}$ & Study period & $\begin{array}{c}\text { Prevalence biopsy } \\
\text { proven (\%) }\end{array}$ & $\begin{array}{c}\text { 95\% Confidence } \\
\text { interval }\end{array}$ \\
\hline Ivarsson et al. (160) & $2005-2006$ & 2.90 & $\begin{array}{c}\text { Prevalence serology } \\
\text { based (\%) }\end{array}$ \\
Tunisia & $2009-2010$ & 2.20 & \\
Hariz et al. (161) & $2003-2005$ & 0.45 & \\
Hariz et al. (162) & 2011 & 0.24 & 0.64 \\
Turkey & & 0.9 & $0.38-0.57$ \\
Demirceken et al. (163) & $2006-2008$ & 0.47 & \\
Dalgic et al. (164) & & & 0.74 \\
United Kindom & 2000 & & $0.09-0.80$ \\
Mustalahti et al. (148) & & 0.31 & 0.9 \\
USA & $1996-2001$ & & \\
Fasano et al. (165) & & & \\
\hline
\end{tabular}

previous diagnosis of $\mathrm{CD}$; thus, the prevalence rate increased to $0.27 \%$ (166). However, this value is still quite low for a country in which screened type 1 diabetes patients are known to often conduct CD as well (10.4\%) (167). The high prevalence rate $(3 \%)$ of CD in Swedish children also can be commented upon (159). In that study in Sweden, the children were born during the epidemic described, experienced high volumes of gluten in their weaning food, and their screening took place when they were 12 years of age. It can be speculated that their high gluten intake at a young age contributed to the $3 \%$ prevalence rate. On the other hand, it should also be noted that in the Swedish study the diagnostic criteria for CD were somewhat unconventional, also including symptomatic patients with only increased intraepithelial lymphocyte counts shown in their biopsy results (Marsh class 1). Patients with no symptoms but exhibiting Marsh 1 lesions were again not considered to have $\mathrm{CD}$. Overall, when comparing the incidence and prevalence studies from different countries in which a biopsy was the primary detection method, the poor celiac center pathologist interobserver reproducibility of the small intestinal mucosal injury, i.e., the Marsh classes, must be kept in mind. A normal mucosa graded as Marsh 0 may be Marsh $3 \mathrm{c}$ and vice versa $(168,169)$.

\section{CONCLUSIONS}

The observed changes in childhood CD presentation and epidemiology have been remarkable during the past 50 years, with overall clinical childhood CD presenting as a malabsorption syndrome transforming into a milder form, resulting in an upward shift of age at diagnosis. The incidence rates and prevalence of childhood CD have been constantly increasing due to case-finding screening strategy. The most important factor in the increasing rates of $\mathrm{CD}$ seemed to be an awareness of healthcare professionals of this changing pattern, the existence of which is quite evidence-based. This change took place at different times in different countries, resulting in several global differences. Today, the best case-finding biomarkers for the screening of undiagnosed CD are gluten-dependent serum autoantibody tests, and it is recommended that these tools be used in the primary care field. There is also evidence of an increase in CD prevalence in children over time that is similar to that observed in adults. The main question involved in this change in prevalence asks for the reasons behind these observed clinical changes. This study thus discusses changing environmental factors, such as breastfeeding, gluten, and cow's milk ingestion, and infections as causes for the observed changes. To prospectively readdress these questions using modern epidemiological tools, it is suggested that studies be conducted in countries in which the classic presentation of $\mathrm{CD}$ in young children, including diarrhea and malabsorption syndrome, still exists. Overall, an oral tolerance toward gluten could still exist in certain settings, and the environmental factors involved in infantile $\mathrm{CD}$ and increasing prevalence of autoimmunity at older ages could still be further investigated by future studies.

\section{AUTHOR CONTRIBUTIONS}

All authors listed have made a substantial, direct, and intellectual contribution to the work, and approved it for publication.

\section{FUNDING}

$\mathrm{AP}$ and $\mathrm{MM}$ were financially supported by the Competitive State Research Financing of the Expert Responsibility Area of Tampere University Hospital, Grant No. 9X035.

\section{REFERENCES}

1. Gee S. On the coeliac affection. St. Bart Hosp Rep. (1890) 24:17-20.

2. Walker-Smith JA. Samuel Gee and the coeliac affection. In: Kumar PJ, Walker-Smith JA, editors. Coeliac Disease: 100 Years. Leeds: The University Printing Service at the University of Leeds. (1988). p. 1-10. 
3. Dicke WK. Coeliakie (thesis). University of Utrecht, Utrecht, Netherlands. (1950).

4. Weijers HA, Lindquist B, Anderson CHM, Rey J, Shmerling DH, Visakorpi JK, et al. Diagnostic criteria in Coeliac disease. Acta Paediatr Scand. (1970) 59:461-3.

5. Visakorpi JK, Immonen P. Intolerance to cow's milk and wheat gluten in the primary malabsorption syndrome in infancy. Acta Paediatr Scand. (1967) 56:49-56. doi: 10.1111/j.1651-2227.1967.tb15343.x

6. Visakorpi JK, Mäki M. Changing clinical features of coeliac disease. Acta Paediatr. (1994) 83:10-3. doi: 10.1111/j.1651-2227.1994.tb13221.x

7. Mäki M. Celiac disease. In: Kleinman RE, Goulet OJ, Mieli-Vergani G, Sanderson IR, Sherman P, Shneider BL, editors. Walker's Pediatric Gastrointestinal Disease. 5th ed. Hamilton: BC Decker Inc. (2008). p. 319-27.

8. Mäki M, Collin P. Coeliac disease. Lancet. (1997) 349:1755-9. doi: 10.1016/S0140-6736(96)70237-4

9. Popp A, Mäki M. Gluten-induced extra-intestinal manifestations in potential celiac disease-celiac trait. Nutrients. (2019) 11:320. doi: 10.3390/nu11020320

10. Nardecchia S, Auricchio R, Discepolo V, Troncone R. Extra-Intestinal manifestations of coeliac disease in children: clinical features and mechanisms. Front Pediatr. (2019) 7:56. doi: 10.3389/fped.2019.00056

11. Seah PP, Fry L, Rossiter MA, Hoffbrand AV, Holborow EJ. Antireticulin antibodies in childhood coeliac disease. Lancet. (1971) 2:681-2. doi: 10.1016/S0140-6736(71)92248-3

12. Mäki M, Hällström O, Vesikari T, Visakorpi JK. J Evaluation of a serum IgA class reticulin antibody test for the detection of childhood celiac disease. $J$ Pediatr. (1984) 105:901-5. doi: 10.1016/S0022-3476(84)80074-8

13. Mäki M, Hällström $O$, Huupponen T, Vesikari T, Visakorpi JK. Increased prevalence of coeliac disease in diabetes. Arch Dis Child. (1984) 59:739-42. doi: 10.1136/adc.59.8.739

14. Ladinser B, Rossipal E, Pittschieler K. Endomysium antibodies in coeliac disease: an improved method. Gut. (1994) 35:776-8. doi: 10.1136/gut.35.6.776

15. Sulkanen S, Halttunen T, Laurila K, Kolho K-L, Korponay-Szabo IR, Sarnesto A, et al. Tissue transglutaminase autoantibody enzyme-linked immunosorbent assay in detecting celiac disease. Gastroenterology. (1998) 115:1322-8. doi: 10.1016/S0016-5085(98)70008-3

16. Korponay-Szabo I, Sulkanen S, Halttunen T, Maurano F, Rossi M, Mazzarella $\mathrm{G}$, et al. Tissue transglutaminase is the target in both rodent and primate tissues for celiac disease-specific autoantibodies. J Pediatr Gastroenterol Nutr. (2000) 31:520-7. doi: 10.1097/00005176-200011000-00013

17. Korponay-Szabó IR, Laurila K, Szondy Z, Halttunen T, Szalai Z, Dahlbom I, et al. Missing endomysial and reticulin binding of coeliac antibodies in transglutaminase 2 knockout tissues. Gut. (2003) 52:199-204. doi: 10.1136/gut.52.2.199

18. Popp A, Mihu M, Munteanu M, Ene A, Dutescu M, Colcer F, et al. Prospective antibody case finding of celiac disease in type-1 diabetes children. Need of biopsy revisited. Acta Paediatr. (2013) 102:e102-6. doi: 10.1111/apa.12117

19. Littlewood JM, Crollick AJ, Richards J. Childhood coeliac disease is disappearing. Lancet. (1980) 2:1359. doi: 10.1016/S0140-6736(80)92417-4

20. Challacombe DN, Baylis JM. Chilshood coeliac disease is disappearing. Lancet. (1980) 2:1360.

21. Dossetor JF, Gibson AA, McNeish AS. Childhood coeliac disease is disappearing. Lancet. (1981) 1:322-3. doi: 10.1016/S0140-6736(81)91926-7

22. Stevens FM, Egan-Mitchell B, Cryan E, McCarthy CF, McNicholl B. Decreasing incidence of coeliac disease. Arch Dis Child. (1987) 62:465-8. doi: 10.1136/adc.62.5.465

23. Mäki M, Kallonen K, Lähdeaho M-L, Visakorpi JK. Changing pattern of childhood coeliac disease in Finland. Acta Paediatr Scand. (1988) 77:408-12. doi: 10.1111/j.1651-2227.1988.tb10668.x

24. Kelly DA, Phillips AD, Elliott EJ, Dias JA, Walker-Smith JA. Rise and fall of coeliac disease 1960-85. Arch Dis Child. (1989) 64:1157-60. doi: $10.1136 /$ adc. 64.8 .1157

25. Verkasalo M, Kuitunen P, Leisti S, Perheentupa J. Growth failure from symptomless celiac disease. A study of 14 patients. Helv Paediatr Acta. (1978) 33:489-95.

26. Cacciari E, Salardi S, Volta U, Biasco G, Lazzari R, Corazza $\mathrm{GR}$, et al. Can antigliadin antibody detect symptomless coeliac disease in children with short stature? Lancet. (1985) 1:1469-71. doi: 10.1016/S0140-6736(85)92251-2

27. Bonamico M, Scire G, Mariani P, Pasquino AM, Triglione P, Scaccia S, et al. Short stature as the primary manifestation of monosymptomatic celiac disease. J Pediatr Gastroenterol Nutr. (1992) 14:12-6. doi: 10.1097/00005176-199201000-00003

28. Mäki M, Hällström O, Verronen P, Reunala T, Lähdeaho ML, Holm K, et al. Reticulin antibody, arthritis, and coeliac disease in children. Lancet. (1988) 1:479-80. doi: 10.1016/S0140-6736(88)91280-9

29. Carroccio A, Iannitto E, Cavataio E, Montalto G, Tumminello M, Campagna $\mathrm{P}$, et al. Sideropenic anemia and celiac disease: One study, two points of view. Dig Dis Sci. (1998) 43:673-8. doi: 10.1023/A:1018896015530

30. Demir H, Yuce A, Kocak N, Ozen H, Gürakan F, et al. Celiac disease in Turkish children: presentation of 104 cases. Pediatr Int. (2000) 42:483-7. doi: 10.1046/j.1442-200x.2000.01286.x

31. Visakorpi JK, Kuitunen P, Savilahti E. Frequency and nature of relapses in children suffering from the malabsorption syndrome with gluten intolerance. Acta Paediatr Scand. (1970) 59:481-6. doi: 10.1111/j.1651-2227.1970.tb16795.x

32. Mäki M, Lähdeaho M-L, Hällström O, Viander M, Visakorpi JK. Postpubertal gluten challenge in coeliac disease. Arch Dis Child. (1989) 64:1604-7. doi: 10.1136/adc.64.11.1604

33. Auricchio S, Mazzacca G, Tosi R, Visakorpi J, Mäki M, Polanco I. Coeliac disease as a familial condition: Identification of asymptomatic coeliac patients within family groups. Gastroenterol Int. (1988) 1:25-31.

34. Mäki $M$, Holm K, Lipsanen V, Hällström $O$, Viander $M$, Collin $P$, et al. Serological markers and HLA genes among healthy first-degree relatives of patients with coeliac disease. Lancet. (1991) 338:1350-3. doi: 10.1016/0140-6736(91)92234-S

35. Mäki M, Holm K, Koskimies S, Hällstrom O, Visakorpi JK. Normal small bowel biopsy followed by celiac disease. Arch Dis Child. (1990) 65:1137-41. doi: 10.1136/adc.65.10.1137

36. Kurppa K, Collin P, Lindfors K, Mäki M, Kaukinen K. Spontaneous negative seroconversion of endomysial antibodies does not exclude subsequent celiac disease. J Pediatr Gastroenterol Nutr. (2011) 53:576-9. doi: 10.1097/MPG.0b013e31821c974f

37. Stenhammar L, Brandt A, Wågemark J. A family study of coeliac disease. Acta Paediatr Scand. (1982) 71:625-8. doi: 10.1111/j.1651-2227.1982.tb09486.x

38. Högberg L, Fälth-Magnusson K, Grodzinsky E, Stenhammar L. Familiar prevalence of coeliac disease: a twenty-year follow-up study. Scand $J$ Gastroenterol. (2003) 38:61-5. doi: 10.1080/00365520310000456

39. Greco L, Mäki M, Di Donato F, Visakorpi JK. Epidemiology of coeliac disease in Europe and the mediterranean area. A summary report on the multicentre study by the European Society of Paediatric Gastroenterology and Nutrition. Dyn Nutr Res. (1992) 2:25-44.

40. Ivarsson A, Persson LA, Nyström L, Ascher H, Cavell B, Danielsson L, et al. Epidemic of coeliac disease in Swedish children. Acta Paediatr. (2000) 89:165-71. doi: 10.1080/080352500750028771

41. Greco L, Tozzi AE, Mayer M, Grimaldi M, Silano G, Auricchio S. Unchanging clinical picture of coeliac disease presentation in Campania, Italy. Eur J Pediatr. (1989) 148:610-3. doi: 10.1007/BF004 41511

42. Garampazzi A, Rapa A, Mura S, Capelli A, Valori A, Boldorini R, et al. Clinical pattern of celiac disease is still changing. J Pediatr Gastroenterol Nutr. (2007) 45:611-4. doi: 10.1097/MPG.0b013e31814c3d79

43. George EK, Mearin ML, Franken HC, Houwen RH, Hirasing RA, Vandenbroucke JP. Twenty years of childhood coeliac disease in tghe Netherlands: a rapidly increasing incidence? Gut. (1997) 40:61-6. doi: 10.1136 /gut.40.1.61

44. Steens RF, Csizmadia CG, George EK, Ninaber MK, Hira Sing RA, Mearin ML. A national prospective study on childhood celiac disease in the Netherlands 1993-2000: an increasing recognition and a changing clinical picture. J Pediatr. (2005) 147:239-43. doi: 10.1016/j.jpeds.2005. 04.013

45. Ravikumara M, Tuthill DP, Jenkins HR. The changing clinical presentation of coeliac disease. Arch Dis Child. (2006) 91:969-71. doi: $10.1136 /$ adc. 2006.094045 
46. Whyte LA, Jenkins HR. The epidemiology of coeliac disease in South Wales: a 28-year perspective. Arch Dis Child. (2013) 98:405-7. doi: 10.1136/archdischild-2012-303113

47. Roma E, Panayiotou J, Karantana H, Constantinidou C, Siakavellas SI, Krini $\mathrm{M}$, et al. Changing pattern in the clinical presentation of pediatric celiac disease: a 30-year study. Digestion. (2009) 80:185-91. doi: 10.1159/000227275

48. McGowan KE, Castiglione DA, Butzner JD. The changing face of childhood celiac disease in North America: impact of serological testing. Pediatrics. (2009) 124:1572-8. doi: 10.1542/peds.2008-2373

49. Telega G, Bennet TR, Werlin S. Emerging new clinical patterns in the presentation of celiac disease. Arch Pediatr Adolesc Med. (2008) 162:164-8. doi: 10.1001/archpediatrics.2007.38

50. Almallouhi E, King KS, Patel B, Wi C, Juhn YJ, Murray JA, et al. Increasing incidence and altered presentation in a population-based study of pediatric celiac disease in North America. J Pediatr Gastroenterol Nutr. (2017) 65:432-7. doi: 10.1097/MPG.0000000000001532

51. Rawal P, Thapa BR, Nain CK, Prasad KK, Singh K. Changing spectrum of celiac disease in India. Iran J Pediatr. (2010) 20:459-65.

52. Bhattacharya M, Kapoor S, Dubey AP. Celiac disease presentation in a tertiary referral centre in India: current scenario. Indian J Gastroenterol. (2013) 32:98-102. doi: 10.1007/s12664-012-0240-y

53. Ress $K$, Luts $K$, Rägo $T$, Pisarev $H$, Uibo $O$. Nationwide study of childhood celiac disease incidence over a 35 -year period in Estonia. Eur J Pediatr. (2012) 171:1823-8. doi: 10.1007/s00431-012-1835-0

54. Gokce S, Arslantas E. Changing face and clinical features of celiac disease in children. Pediatr Int. (2015) 57:107-12. doi: 10.1111/ped.12448

55. Tapsas D, Hollén E, Stenhammar L, Fälth-Magnusson K. The clinical presentation of coeliac disease in 1030 Swedish children: changing features over the past four decades. Dig Liver Dis. (2016) 48:16-22. doi: 10.1016/j.dld.2015.09.018

56. Savilahti E, Kolho KL, Westerholm-Ormio M, Verkasalo M. Clinics of coeliac disease in children in the 2000s. Acta Paediatr. (2010) 99:1026-30. doi: 10.1111/j.1651-2227.2010.01740.x

57. Ascher H, Holm K, Kristiansson B, Mäki M. Different features of coeliac disease in two neighbouring countries. Arch Dis Child. (1993) 69:375-80. doi: 10.1136/adc.69.3.375

58. Kivelä L, Kaukinen K, Lähdeaho ML, Huhtala H, Ashorn M, Ruuska $\mathrm{T}$, et al. Presentation of celiac disease in Finnish children is no longer changing: a 50-year perspective. J Pediatr. (2015) 167:1109-15. doi: 10.1016/j.jpeds.2015.07.057

59. Hill ID, Bhatnagar S, Cameron DJS, De Rosa S, Maki M, Russell GJ, et al. Celiac disease: working group report of the First World Congress of Pediatric Gastroenterology, Hepatology, and Nutrition. J Pediatr Gstroenterol Nutr. (2002) 35:S78-88. doi: 10.1097/00005176-200208002-00004

60. Hill ID, Dirks MH, Liptak GS, Colletti RB, Fasano A, Guandalini S, et al. Guideline for the diagnosis and treatment of celiac disease in children: recommendations of the North American Society for Pediatric Gastroenterology, Hepatology and Nutrition. J Pediatr Gastroenterol Nutr. (2005) 40:1-19. doi: 10.1097/00005176-200501000-00001

61. Husby S, Koletzko S, Korponay-Szabó IR, Mearin ML, Phillips A, Shamir R, et al. European Society for Pediatric Gastroenterology, Hepatology, and Nutrition guidelines for the diagnosis of coeliac disease. J Ped Gastroenterol Nutr. (2012) 54:136-60. doi: 10.1097/MPG.0b013e31821a23d0

62. Mäki M, Holm K, Ascher H, Greco L. Factors affecting clinical presentation of coeliac disease: role of type and amount of gluten-containing cereals in the diet. Dyn Nutr Res. (1992) 2:76-82.

63. Andersen DH, di Sant'Agnese PA. Idiopathic celiac disease. I. Mode of onset and diagnosis. Pediatrics. (1953) 11:207-23.

64. Auricchio S, Follo D, de Ritis G, Giunta A, Marzorati D, Prampolini L, et al. Does breast feeding protect against the development of clinical symptoms of celiac disease in children? J Pediatr Gastroenterol Nutr. (1983) 2:428-33. doi: 10.1097/00005176-198302030-00006

65. Greco L, Mayer M, Grimaldi M, Follo D, De Ritis G, Auricchio S. The effect of early feeding on the onset of symptoms in celiac disease. J Pediatr Gastroenterol Nutr. (1985) 4:52-5. doi: 10.1097/00005176-198502000-00010

66. Ivarsson A, Hernell O, Stenlund H, Persson LA. Breast-feeding protects against celiac disease. Am J Clin Nutr. (2002) 75:914-21. doi: $10.1093 /$ ajcn/75.5.914
67. Akobeng AK, Ramanan AV, Buchan I, Heller RF. Effect of breast feeding on risk of coeliac disease: a systematic review and meta-analysis of observational studies. Arch Dis Child. (2006) 91:39-43. doi: 10.1136/adc.2005.082016

68. Szajewska H, Chmielewska A, Pieścik-Lech M, Ivarsson A, Kolacek S, Koletzko S, et al. Systematic review: early infant feeding and the prevention of coeliac disease. Aliment Pharmacol Ther. (2012) 36:607-18. doi: 10.1111/apt.12023

69. Szajewska H, Shamir R, Mearin L, Ribes-Koninckx C, Catassi C, Domellöf $\mathrm{M}$, et al. Gluten Introduction and the risk of coeliac disease: a position paper by the European Society for Pediatric Gastroenterology, Hepatology, and Nutrition. J Pediatr Gastroenterol Nutr. (2016) 62:507-13. doi: 10.1097/MPG.0000000000001105

70. Lionetti E, Castellaneta S, Francavilla R, Pulvirenti A, Tonutti E, Amarri S, et al. Introduction of gluten, HLA status, and the risk of celiac disease in children. N Engl J Med. (2014) 371:1295-303. doi: 10.1056/NEJMoa1400697

71. Vriezinga SL, Auricchio R, Bravi E, Castillejo G, Chmielewska A, Crespo Escobar P, et al. Randomized feeding intervention in infants at high risk for celiac disease. N Engl J Med. (2014) 371:1304-15. doi: 10.1056/NEJMoa1404172

72. Størdal K, Richard A, Eggsbø M. Early feeding and risk of celiac disease in a prospective birth cohort. Pediatrics. (2013) 132:e1202-9. doi: $10.1542 /$ peds.2013-1752

73. Meijer C, Shamir R, Szajewska H, Mearin L. Celiac disease prevention. Front Pediatr. (2018) 6:368. doi: 10.3389/fped.2018.00368

74. Högberg L, Laurin P, Fälth-Magnusson K, Grant C, Grodzinsky E, Jansson $\mathrm{G}$, et al. Oats to children with newly diagnosed coeliac disease: a randomised double blind study. Gut. (2004) 53:649-54. doi: 10.1136/gut.2003.026948

75. Holm K, Mäki M, Vuolteenaho N, Mustalahti K, Ashorn M, Ruuska T, et al. Oats in the treatment of childhood coeliac disease: a 2-year controlled trial and a long-term clinical follow-up study. Aliment Pharmacol Ther. (2006) 23:1463-72. doi: 10.1111/j.1365-2036.2006.02908.x

76. Lionetti E, Gatti S, Galeazzi T, Caporelli N, Francavilla R, Cucchiara S, et al. Safety of oats in children with celiac disease: a double-blind, randomized, placebo-controlled trial. J Pediatr. (2018) 194:116-22.e2. doi: $10.1016 /$ j.jpeds.2017.10.062

77. Weile B, Cavell B, Nivenius K, Krasilnikoff PA. Striking differences in the incidence of childhood celiac disease between Denmark and Sweden: a plausible explanation. J Pediatr Gastroenterol Nutr. (1995) 21:64-8. doi: 10.1097/00005176-199507000-00011

78. Mitt K, Uibo O. Low cereal intake in Estonian infants: the possible explanation for the low frequency of coeliac disease in Estonia. Eur J Clin Nutr. (1998) 52:85-8. doi: 10.1038/sj.ejcn.1600511

79. Crespo-Escobar P, Mearin ML, Hervás D, Auricchio R, Castillejo G, Gyimesi J, et al. The role of gluten consumption at an early age in celiac disease development: a further analysis of the prospective PreventCD cohort study. Am J Clin Nutr. (2017) 105:890-6. doi: 10.3945/ajcn.116. 144352

80. Mårild K, Dong F, Lund-Blix NA, Seifert J, Barón AE, Waugh KC, et al. Gluten intake and risk of celiac disease: long-term followup of an at-risk birth cohort. Am J Gastroenterol. (2019) 114:1-8. doi: $10.14309 /$ ajg.0000000000000255

81. van den Broeck HC, de Jong HC, Salentijn EM, Dekking L, Bosch D, Hamer RJ, et al. Presence of celiac disease epitopes in modern and old hexaploid wheat varieties: wheat breeding may have contributed to increased prevalence of celiac disease. Theor Appl Genet. (2010) 121:1527-39. doi: 10.1007/s00122-010-1408-4

82. de Lorgeril M, Salen P. Gluten and wheat intolerance today: are modern wheat strains involved? Int J Food Sci Nutr. (2014) 65:577-81. doi: $10.3109 / 09637486.2014 .886185$

83. Mäki M, Holm K. Incidence and prevalence of coeliac disease in Tampere. Coeliac disease is not disappearing. Acta Paediatr Scand. (1990) 79:980-2. doi: 10.1111/j.1651-2227.1990.tb11367.x

84. Kuitunen P, Visakorpi JK, Savilahti E, Pelkonen P. Malabsorption syndrome with cow's milk intolerance. Clinical findings and course in 54 cases. Arch Dis Child. (1975) 50:351-6. doi: 10.1136/adc.50.5.351

85. Kuitunen P, Visakorpi JK, Hallman N. Histopathology of duodenal mucosa in malabsorption syndrome induced by cow's milk. Ann Paediatr. (1965) 205:54-63. 
86. Kuitunen P, Rapola J, Savilahti E, Visakorpi JK. Response of the jejunal mucosa to cow's milk in the malabsorption syndrome with cow's milk intolerance. A light- and electron-microscopic study. Acta Paediatr Scand. (1973) 62:585-95. doi: 10.1111/j.1651-2227.1973.tb17069.x

87. Hyytinen M, Savilahti E, Virtanen SM, Härkönen T, Ilonen J, Luopajärvi $\mathrm{K}$, et al. Avoidance of cow's milk-based formula for at-risk infants does not reduce development of celiac disease: a randomized controlled trial. Gastroenterology. (2017) 153:961-70.e3. doi: 10.1053/j.gastro.2017.06.049

88. Zanoni G, Navone R, Lunardi C, Tridente G, Bason C, Sivori S, et al. In celiac disease, a subset of autoantibodies against transglutaminase binds toll-like receptor 4 and induces activation of monocytes. PLoS ONE. (2006) 3:e358. doi: 10.1371/journal.pmed.0030358

89. Stene LC, Honeyman MC, Hoffenberg EJ, Haas JE, Sokol RJ, Emery L, et al. Rotavirus infection frequency and risk of celiac disease autoimmunity in early childhood: a longitudinal study. Am J Gastroenterol. (2006) 101:233340. doi: 10.1111/j.1572-0241.2006.00741.x

90. Kemppainen K, Lynch K, Liu E, Lönnrot M, Simell V, Briese T, et al. Factors that increase risk of celiac disease autoimmunity after a gastrointestinal infection in early life. Clin Gastroenterol Hepatol. (2017) 15:694-702.e5. doi: 10.1016/j.cgh.2016.10.033

91. Davidson GP, Gall DG, Petric M, Butler DG, Hamilton JR. Human rotavirus enteritis induced in conventional piglets. J Clin Invest. (1977) 60:1402-9. doi: 10.1172/JCI108901

92. Davidson GP, Barnes GL. Structural and functional abnormalities of the small intestine in infants and young children with rotavirus enteritis. Acta Paediatr Scand. (1979) 68:181-6. doi: 10.1111/j.1651-2227.1979.tb04986.x

93. Bouziat R, Hinterleitner R, Brown J, Stencel-Baerenwald JE, Ikizler M, Mayassi $\mathrm{T}$, et al. Reovirus infection triggers inflammatory responses to dietary antigens and development of celiac disease. Science. (2017) 356:4450. doi: 10.1126/science.aah5298

94. Kahrs CR, Chuda K, Tapia G, Stene LC, Mårild K, Rasmussen T, et al. Enterovirus as trigger of coeliac disease: nested case-control study within prospective birth cohort. BMJ. (2019) 364:1231. doi: 10.1136/bmj.1231

95. Myléus A, Hernell O, Gothefors L, Hammarström ML, Persson LÅ, Stenlund $\mathrm{H}$, et al. Early infections are associated with increased risk for celiac disease: an incident case-referent study. BMC Pediatr. (2012) 12:194. doi: 10.1186/1471-2431-12-194

96. Mårild K, Kahrs CR, Tapia G, Stene LC, Størdal K. Infections and risk of celiac disease in childhood: a prospective nationwide cohort study. Am J Gastroenterol. (2015) 110:1475-84. doi: 10.1038/ajg.2015.287

97. Vaarala O, Jokinen J, Lahdenkari M, Leino T. Rotavirus vaccination and the risk of celiac disease or type 1 diabetes in Finnish children at early life. Pediatr Infect Dis J. (2017) 36:674-5. doi: 10.1097/INF.0000000000001600

98. Hemming-Harlo M, Lähdeaho ML, Mäki M, Vesikari T. Rotavirus vaccination does not increase type 1 diabetes and may decrease celiac disease in children and adolescents. Pediatr Infect Dis J. (2019) 38:539-41. doi: 10.1097/INF.0000000000002281

99. Tye-Din JA, Galipeau HJ, Agardh D. Celiac disease: a review of current concepts in pathogenesis, prevention, and novel therapies. Front Pediatr. (2018) 6:350. doi: 10.3389/fped.2018.00350

100. Sander SD, Nybo Andersen AM, Murray JA, Karlstad Ø, Husby S, Størdal K. Association between antibiotics in the first year of life and celiac disease. Gastroenterology. (2019) 156:2217-29. doi: 10.1053/j.gastro.2019.02.039

101. Mäki M, Vesikari T, Isolauri E. Changing pattern of acute childhood diarrhoea (in Finnish). Duodecim. (1983) 99:754-61.

102. Mäki M. A prospective clinical study of rotavirus diarrhoea in young children. Acta Paediatr Scand. (1981) 70:107-13. doi: 10.1111/j.1651-2227.1981.tb07181.x

103. Vesikari T, Mäki M, Sarkkinen HK, Arstila P, Halonen PE. Rotavirus, adenovirus, and non- viral enteropathogens in diarrhoea. Arch Dis Child. (1981) 56:264-70. doi: 10.1136/adc.56.4.264

104. Bach JF. The effect of infections on susceptibility to autoimmune and allergic diseases. $N$ Engl J Med. (2002) 347:911-20. doi: 10.1056/NEJMra0 20100

105. Bach JF. The hygiene hypothesis in autoimmunity: the role of pathogens and commensals. Nat Rev Immunol. (2018) 18:105-20. doi: 10.1038/nri.2017.111

106. Vatanen T, Kostic AD, d'Hennezel E, Siljander H, Franzosa EA, Yassour $M$, et al. Variation in microbiome LPS immunogenicity contributes to autoimmunity in humans. Cell. (2016) 165:842-53. doi: 10.1016/j.cell.2016.04.007

107. Mäki M, Hällström O, Marttinen A. Reaction of human non-collagenous polypeptides with coeliac disease autoantibodies. Lancet. (1991) 338:724-5. doi: 10.1016/0140-6736(91)91445-Z

108. Mäki M. Autoantibodies as markers of autoimmunity in coeliac disease pathogenesis. In: Feighery C, O’Farrelly C, editors. Gastrointestinal Immunology and Gluten-Sensitive Disease. Dublin: Oak Tree Press (1994). p. $246-52$.

109. Mäki M. Coeliac disease and autoimmunity due to unmasking of cryptic epitopes? Lancet. (1996) 348:1046-7. doi: 10.1016/S0140-6736(05)64411-X

110. Sollid LM, Jabri B. Triggers and drivers of autoimmunity: lessons from coeliac disease. Nat Rev Immunol. (2013) 13:294-302. doi: 10.1038/nri3407

111. Logan RF, Tucker G, Rifkind EA, Heading RC, Ferguson A. Changes in clinical features of coeliac disease in adults in Edinburgh and the Lothians 1960-79. Br Med J. (1983) 286:95-7. doi: 10.1136/bmj.286.6359.95

112. Collin P, Reunala $\mathrm{T}$, Rasmussen $\mathrm{M}$, Kyrönpalo S, Pehkonen E, Laippala $\mathrm{P}$, et al. High incidence and prevalence of adult celiac disease: augmented diagnostic approach. Scand J Gastroenterol. (1997) 32:1129-33. doi: 10.3109/00365529709002992

113. Mäki M, Mustalahti K, Kokkonen J, Kulmala P, Haapalahti M, Karttunen T, et al. Prevalence of celiac disease among children in Finland. $N$ Engl J Med. (2003) 348:2517-24. doi: 10.1056/NEJMoa021687

114. Lohi S, Mustalahti K, Kaukinen K, Laurila K, Collin P, Rissanen H, et al. Increasing prevalence of coeliac disease over time. Aliment Pharmacol Ther. (2007) 26:1217-25. doi: 10.1111/j.1365-2036.2007.03502.x

115. Vilppula A, Kaukinen K, Luostarinen L, Krekelä I, Patrikainen H, Valve $\mathrm{R}$, et al. Increasing prevalence and high incidence of celiac disease in elderly people: a population-based study. BMC Gastroenterol. (2009) 9:49. doi: 10.1186/1471-230X-9-49

116. Rubio-Tapia A, Kyle RA, Kaplan EL, Johnson DR, Page W, Erdtmann F, et al. Increased prevalence and mortality in undiagnosed celiac disease. Gastroenterology. (2009) 137:88-93. doi: 10.1053/j.gastro.2009.03.059

117. Catassi C, Kryszak D, Bhatti B, Sturgeon C, Helzlsouer K, Clipp SL, et al. Natural history of celiac disease autoimmunity in a USA cohort followed since 1974. Ann Med. (2010) 42:530-8. doi: 10.3109/07853890.2010.514285

118. White LE, Merrick VM, Bannerman E, Russell RK, Basude D, Henderson $\mathrm{P}$, et al. The rising incidence of celiac disease in Scotland. Pediatrics. (2013) 132:e924-31. doi: 10.1542/peds.2013-0932

119. Beitnes AR, Vikskjold FB, Jóhannesdóttir GB, Perminow G, Olbjørn C, Andersen SN, et al. Symptoms and mucosal changes stable during rapid increase of pediatric celiac disease in Norway. J Pediatr Gastroenterol Nutr. (2017) 64:586-91. doi: 10.1097/MPG.0000000000001307

120. Catassi C, Fabiani E, Rätsch IM, Coppa GV, Giorgi PL, Pierdomenico R, et al. The coeliac iceberg in Italy. A multicentre antigliadin antibodies screening for coeliac disease in school-age subjects. Acta Paediatr Suppl. (1996) 412:29-35. doi: 10.1111/j.1651-2227.1996.tb14244.x

121. Gatti S, Lionetti E, Balanzoni L, Verma AK, Galeazzi T, Gesuita R, et al. Increased prevalence of celiac disease in school-age children in Italy. Clin Gastroenterol Hepatol. (2019). doi: 10.1016/j.cgh.2019.06.013. [Epub ahead of print].

122. Kondrashova A, Reunanen A, Romanov A, Karvonen A, Viskari H, Vesikari $\mathrm{T}$, et al. A six-fold gradient in the incidence of type 1 diabetes at the eastern border of Finland. Ann Med. (2005) 37:67-72. doi: 10.1080/07853890410018952

123. Kondrashova A, Mustalahti K, Kaukinen K, Viskari H, Volodicheva V, Haapala AM, et al. Lower economic status and inferior hygienic environment may protect against celiac disease. Ann Med. (2008) 40:223-31. doi: 10.1080/07853890701678689

124. Weile B, Krasilnikoff PA. Low incidence rates by birth of symptomatic coeliac disease in a Danish population of children. Acta Paediatr. (1992) 81:394-8. doi: 10.1111/j.1651-2227.1992.tb12256.x

125. George EK, Mearin ML, van der Velde EA, Houwen RH, Bouquet J, Gijsbers $\mathrm{CF}$, et al. Low incidence of childhood celiac disease in the Netherlands. Pediatr Res. (1995) 37:213-8. doi: 10.1203/00006450-199502000-00015

126. George EK, Jansen TL, Mearin ML, Mulder CJ. Epidemiology of celiac disease in the Netherlands. J Pediatr Gastroenterol Nutr. (1997) 24:S7-9. doi: 10.1097/00005176-199700001-00003 
127. Michaelsen KF, Weile B, Larsen P, Samuelson G, Krasilnikoff PA. Does the low intake of wheat in Danish infants cause the low incidence rate of coeliac disease? Acta Paediatr. (1993) 82:605-6. doi: 10.1111/j.1651-2227.1993.tb12767.x

128. Dydensborg S, Toftedal P, Biaggi M, Lillevang ST, Hansen DG, Husby S. Increasing prevalence of coeliac disease in Denmark: a linkage study combining national registries. Acta Paediatr. (2012) 101:179-84. doi: 10.1111/j.1651-2227.2011.02392.x

129. Grode L, Bech BH, Jensen TM, Humaidan P, Agerholm IE, PlanaRipoll O, et al. Prevalence, incidence, and autoimmune comorbidities of celiac disease: a nation-wide, population-based study in Denmark from 1977 to 2016. Eur J Gastroenterol Hepatol. (2018) 30:83-91. doi: 10.1097/MEG.0000000000000992

130. Zingone F, West J, Auricchio R, Maria Bevilacqua R, Bile G, Borgheresi $\mathrm{P}$, et al. Incidence and distribution of coeliac disease in Campania. (Italy):2011-2013. United Euro Gastroenterol J. (2015) 3:182-9. doi: $10.1177 / 2050640615571021$

131. Magazzu G, Bottaro G, Cataldo F, Iacono G, Di Donato F, Patane $\mathrm{R}$, et al. Increasing incidence of childhood celiac disease in Sicily: results of a multicenter study. Acta Paediatr. (1994) 83:1065-9. doi: 10.1111/j.1651-2227.1994.tb12987.x

132. Zingone F, West J, Crooks CJ, Fleming KM, Card TR, Ciacci $\mathrm{C}$, et al. Socioeconimic variation in the incidence of childhood celiac disease in the UK. Arch Dis Child. (2015) 100:466-73. doi: 10.1136/archdischild-2014-307105

133. Tapsas D, Hollen E, Stenhammar L, Fälth-Magnusson K. Unusually high incidence of paediatric coeliac disease in Sweden during the period 19732013. PLoS ONE. (2015) 10:e0144346. doi: 10.1371/journal.pone.0144346

134. Chin MW, Mallon DF, Cullen DJ, Olynyk JK, Mollison LC, Pearce CB. Screening for coeliac disease using anti-tissue transglutaminase antibody assays, and prevalence of the disease in an Australian community. Med J Aust. (2009) 190:429-32.

135. Mora M, Litwin N, Toca Mdel C, Azacona MI, Solis Neffa RS, Battiston F, et al. Prevalence of celiac disease: multicentric trial among pediatric population from five urban districts in Argentina. Arch Argent Pediatr. (2012) 110:490-6. doi: 10.5546/aap.2012.eng.490

136. Pratesi R, Gandolfi L, Garcia SG, Modelli IC, Lopes de Almeida P, Bocca AL, et al. Prevalence of coeliac disease: unexplained age-related variation in the same population. Scand J Gastroenterol. (2003) 38:747-50. doi: 10.1080/00365520310003255

137. Abu-Zekry M, Kryszak D, Diab M, Catassi C, Fasano A. Prevalence of celiac disease in Egyptian children disputes the east-west agriculturedependent spread of the disease. J Pediatr Gastroenterol Nutr. (2008) 47:136-40. doi: 10.1097/MPG.0b013e31815ce5d1

138. Ress K, Harro M, Maaroos HI, Harro J, Uibo R, Uibo O. High prevalence of coeliac disease: need for increasing awareness among physicians. Dig Liver Dis. (2007) 39:136-9. doi: 10.1016/j.dld.2006.07.012

139. Lillemae K, Ress K, Harro J, Merenakk L, Maaroos HI, Uibo R, et al. A 10year serological follow-up of celiac disease in an Estonian population. Eur J Gastrenterol Hepatol. (2012), 24:55-8. doi: 10.1097/MEG.0b013e32834d09b9

140. Laass MW, Schmitz R, Uhlig HH, Zimmer KP, Thamm M, Koletzko S. The prevalence of celiac disease in children and adolescents in Germany. Dtsch Arztebl Int. (2015) 112:553-60. doi: 10.3238/arztebl.2015.0553

141. Karagiozoglou-Lampoudi T, Zellos A, Vlahavas G, Kafritsa Y, Roma E, Papadopoulou A, et al. Screening for coeliac disease in preschool Greek children: the feasibility study of a community-based project. Acta Paediatr. (2013) 102:749-54. doi: 10.1111/apa.12241

142. Korponay-Szabó IR, Kovács JB, Czinner A, Goracz G, Vamos A, Szabo T. High prevalence of silent celiac disease in preschool children screened with IgA/IgG antiendomysium antibodies. J Pediatr Gastroenterol Nutr. (1999) 28:26-30. doi: 10.1097/00005176-199901000-00008

143. Korponay-Szabó IR, Szabados K, Pusztai J, Uhrin K, Ludmany E, Nemes $\mathrm{E}$, et al. Population screening for coeliac disease in primary care by district nurses using a rapid antibody test: diagnostic accuracy and feasibility study. Br Med J. (2007) 335:1244-7. doi: 10.1136/bmj.39405.472975.80

144. Makharia GK, Verma AK, Amarchand R, Bhatnagar S, Das P, Goswami $A$, et al. Prevalence of celiac disease in the northern part of India: a community based study. J Gastroenterol Hepatol. (2011) 26:894-900. doi: 10.1111/j.1440-1746.2010.06606.x

145. Farahmand F, Mir-Nasseri MM, Shahraki T, Yourdkhani F, Ghotb S, Modaresi V, et al. Prevalence of occult celiac disease in healthy Iranian school age children. Arch Iran Med. (2012) 15:342-5.

146. Dehghani SM, Haghighat M, Mobayen A, Rezaianz a, Geramizadeh B. Prevalence of celiac disease in healthy Iranian school children. Ann Saudi Med. (2013) 33:159-61. doi: 10.5144/0256-4947.2013.159

147. Tommasini A, Not T, Kiren V, Santon D, Trevisiol C, Berti I, et al. Mass screening for coeliac disease using antihuman transglutaminase antibody assay. Arch Dis Child. (2004) 89:512-5. doi: 10.1136/adc.2003.029603

148. Mustalahti K, Catassi C, Reunanen A, Fabiani E, Heier M, McMillan $\mathrm{S}$, et al. The prevalence of celiac disease in Europe: results of a centralized, international mass screening project. Ann Med. (2010) 42:58795. doi: 10.3109/07853890.2010.505931

149. Bonamico M, Nenna R, Montuori M, Luparia RPL, Turchetti A, Mennini M, et al. First salivary screening of celiac disease by detection of antitransglutaminase autoantibody radioimmunoassay in 5000 Italian primary schoolchildren. J Pediatr Gastroenterol Nutr. (2011) 52:17-20. doi: 10.1097/MPG.0b013e3181e6f2d0

150. Csizmadia CG, Mearin ML, von Blomberg BM, Brand R, VerlooveVanhorick SP. An iceberg of childhood coeliac disease in the Netherlands. Lancet. (1999) 353:813-4. doi: 10.1016/S0140-6736(99)00243-3

151. Stordal K, Bakken IJ, Suren P, Stene LC. Epidemiology of coeliac disease and comorbidity in Norwegian children. J Pediatr Gastroenterol Nutr. (2013) 57:467-71. doi: 10.1097/MPG.0b013e3182a455dd

152. Al-Hussaini A, Troncone R, Khormi M, AlTuraiki M, Alkhamis W, Alrajhi $\mathrm{M}$, et al. Mass screening for celiac disease among school-aged children: toward exploring celiac Iceberg in Saudi Arabia. J Pediatr Gastroenterol Nutr. (2017) 65:646-51. doi: 10.1097/MPG.0000000000001681

153. Almazán MV, Ortega E, Moreno Torres R, Vilar P, Cortijo M, Salas A, et al. Diagnostic screening for subclinical celiac disease using a rapid test in children aged 2-4. Pediatr Res. (2015) 78:280-5. doi: 10.1038/pr.2015.98

154. Cilleruelo ML, Fernández-Fernández S, Jiménez-Jiménez J, Rayo AI, de Larramendi $\mathrm{CH}$. Prevalence and natural history of celiac disease in a cohort of at-risk children. J Pediatr Gastroenterol Nutr. (2016) 62:739-45. doi: 10.1097/MPG.0000000000001007

155. Marine M, Farre C, Alsina M, Vilar P, Cortijo M, Salas A, et al. The prevalence of coeliac disease is significantly higher in children compared with adults. Aliment Pharmacol Ther. (2011) 33:477-86. doi: 10.1111/j.1365-2036.2010.04543.x

156. Castaño L, Blarduni E, Ortiz L, Bilbao JR, Rica I, Martul P, et al. Prospective population screening for celiac disease: high prevalence in the first 3 years of life. J Pediatr Gastroenterol Nutr. (2004) 39:80-4. doi: 10.1097/00005176-200407000-00016

157. Carlsson AK, Axelsson IE, Borulf SK, Melton LJ, Krause K, Maggi K, et al. Serological screening for celiac disease in healthy 2.5 -year-old children in Sweden. Pediatrics. (2001) 107:42-5. doi: 10.1542/peds.107.1.42

158. Carlsson A, Agardh D, Borulf S, Grodzinsky E, Axelsson I, Ivarsson SA. Prevalence of celiac disease: before and after a national change in feeding recommendations. Scand J Gastroenterol. (2006) 41:553-8. doi: 10.1080/00365520500352600

159. Myléus A, Ivarsson A, Webb C, Danielsson L, Hernell O, Hogberg $\mathrm{L}$, et al. Celiac disease revealed in $3 \%$ of Swedish 12-year-olds born during an epidemic. J Pediatr Gastroenterol Nutr. (2009) 49:170-6. doi: 10.1097/MPG.0b013e31818c52cc

160. Ivarsson A, Myléus A, Norström F, Van Der Pals M, Rosen A, Hogberg L, et al. Prevalence of childhood celiac disease and changes in infant feeding. Pediatrics. (2013) 131:e687-94. doi: 10.1542/peds.2012-1015

161. Hariz MB, Kallel-Sellami M, Kallel L, Lahmer A, Halioui S, Bouraoui $\mathrm{S}$, et al. Prevalence of celiac disease in Tunisia: mass-screening study in schoolchildren. Eur J Gastroenterol Hepatol. (2007) 19:687-94. doi: 10.1097/MEG.0b013e328133f0c1

162. Hariz MB, Laadhar L, Kallel-Sellami M, Siala N, Bouraoui S, Bouziri $S$, et al. Celiac disease in Tunisian children: a second screening study using a "new generation" rapid test. Immunol Invest. (2013) 42:356-68. doi: 10.3109/08820139.2013.770012 
163. Demirçeken FG, Kansu A, Kuloglu Z, Girgin N, Guriz H, Ensari A. Human tissue transglutaminase antibody screening by immunochromatographic line immunoassay for early diagnosis of celiac disease in Turkish children. Turk J Gastroenterol. (2008) 19:14-21.

164. Dalgic B, Sari S, Basturk B, Ensari A, Egritas O, Bukulmez A, et al. Prevalence of celiac disease in healthy Turkish school children. Am J Gastroenterol. (2011) 106:1512-7. doi: 10.1038/ajg.2011.183

165. Fasano A, Berti I, Gerarduzzi T, Not T, Colletti RB, Drago S, et al. Prevalence of celiac disease in at-risk and not-at-risk groups in the United States: a large multicenter study. Arch Intern Med. (2003) 163:286-92. doi: 10.1001/archinte.163.3.286

166. Toftedal P, Hansen DG, Nielsen C, Lillevang ST, Hansen TP, Husby S. Questionnaire-based case finding of celiac disease in a population of 8- to 9-year-old children. Pediatrics. (2010) 125:e518-24. doi: 10.1542/peds.2009-0375

167. Hansen D, Bennedbaek FN, Hansen LK, Høier-Madsen M, Hegedü LS, Jacobsen BB, et al. High prevalence of coeliac disease in Danish children with type I diabetes mellitus. Acta Paediatr. (2001) 90:1238-43. doi: $10.1080 / 080352501317130254$
168. Werkstetter K, Korponay-Szabó I, Popp A, Villanacci V, Salemme M, Heilig G, et al. Accuracy in diagnosis of celiac disease without biopsies in clinical practice. Gastroenterology. (2017) 153:924-35. doi: 10.1053/j.gastro.2017.06.002

169. Taavela J, Koskinen O, Huhtala H, Lähdeaho M-L, Popp A, Laurila $\mathrm{K}$, et al. Validation of morphometric analyses of small-intestinal biopsy readouts in celiac disease. PLoS ONE. (2013) 8:e76163. doi: 10.1371/journal.pone. 0076163

Conflict of Interest Statement: The authors declare that the research was conducted in the absence of any commercial or financial relationships that could be construed as a potential conflict of interest.

Copyright $\odot 2019$ Popp and Mäki. This is an open-access article distributed under the terms of the Creative Commons Attribution License (CC BY). The use, distribution or reproduction in other forums is permitted, provided the original author(s) and the copyright owner(s) are credited and that the original publication in this journal is cited, in accordance with accepted academic practice. No use, distribution or reproduction is permitted which does not comply with these terms. 